\title{
Maize Milling By-Products: From Food Wastes to Functional Ingredients Through Lactic Acid Bacteria Fermentation
}

\author{
Erica Pontonio ${ }^{*}$, Cinzia Dingeo', Marco Gobbetti2 and Carlo Giuseppe Rizzello1 \\ ${ }^{1}$ Department of Soil, Plant and Food Sciences, University of Bari Aldo Moro, Bari, Italy, ${ }^{2}$ Faculty of Science and Technology, \\ Free University of Bozen-Bolzano, Bolzano, Italy
}

\section{OPEN ACCESS}

Edited by:

Vittorio Capozzi,

University of Foggia, Italy

Reviewed by:

Maija Tenkanen,

University of Helsinki, Finland

Elena Bartkiene,

Lithuanian University of Health

Sciences, Lithuania

*Correspondence:

Erica Pontonio

erica.pontonio@uniba.it;

ericapontonio@gmail.com

Specialty section:

This article was submitted to

Food Microbiology,

a section of the journal

Frontiers in Microbiology

Received: 10 January 2019

Accepted: 05 March 2019

Published: 19 March 2019

Citation:

Pontonio E, Dingeo C, Gobbetti M and Rizzello CG (2019) Maize Milling

By-Products: From Food Wastes to Functional Ingredients Through Lactic Acid Bacteria Fermentation.

Front. Microbiol. 10:561.

doi: 10.3389/fmicb.2019.00561
Although recognized as important sources of functional compounds, milling by-products are often removed from the cereal kernel prior milling process. Indeed, the high presence of fiber in bran and the co-presence of lipids and lipase in germ are often considered as downsides for breadmaking. In this work, Lactobacillus plantarum T6B10 and Weissella confusa BAN8 were used as selected starters to ferment maize milling byproducts mixtures made with heat-treated or raw germ and bran. The effects on the biochemical and nutritional features as well as the stability of the milling by-products were investigated. Lactic acid bacteria metabolisms improved the free amino acids and peptides concentrations and the antioxidant activity and caused a relevant phytic acid degradation. Moreover, fermentation allowed a marked decrease of the lipase activity, stabilizing the matrix by preventing oxidative processes. The use of fermented by-products as ingredients improved the nutritional, textural and sensory properties of wheat bread. Fortified breads (containing 25\% of fermented by-products) were characterized by a concentration in dietary fiber and proteins of ca. 11 and $13 \%$ of dry matter, respectively. Compared to the use of the unfermented ones, the addition of prefermented by-products to bread caused a significant increase in protein digestibility (up to $60 \%$ ), and a relevant decrease of the starch hydrolysis index (ca. 13\%). According to the results, this study demonstrates the potential of fermentation to convert maize bran and germ, commonly considered food wastes, into nutritive improvers, meeting nutritional and sensory requests of modern consumers.

Keywords: maize, milling by-products, lactic acid fermentation, high-fiber, nutritional profile

\section{INTRODUCTION}

The World Health Organization (WHO) stated, in 2016, that more than 1.9 billion adults were overweight and more than 600 million obese (WHO, 2018), probably due to the radical changes of the dietary habits recorded through the past decades (Fernstrand et al., 2017). The average daily intake of fiber in many populations is still lower than those recommended (Stephen et al., 2017), although the consumers are already aware of the advantages of a healthy diet rich in dietary fiber. Indeed, numerous physiological effects have been highlighted, i.e., the prevention of coronary heart 
disease, type 2 diabetes, colorectal and other types of cancers (Kaczmarczyk et al., 2012) as well as it seems to be inversely associated with body weight due to the suppressing effect on the energy intake through increasing satiation (Howarth et al., 2001). Fortification of a staple food, i.e., bread, represents a promising way to increase fiber intake. However, it is needed to be able to produce healthy, fiber-rich bakery products with an appealing texture and taste. Optimal diet rich in fiber refers at the same time to the right amount and a suitable balance between them. The production of multi-grain products makes it possible, providing more variety in breads and increasing the diversity in fermentable soluble fiber (Lopez et al., 2001). The need for food companies to produce dietary fibers-enriched as well as low-calorific foods to meet the consumers requirements, is leading to investments in allocating resources in innovative foods developments. In this scenario, several scientific researches have been carried out aiming at substituting wheat flour in bread formulations (Sivam et al., 2010; Preedy et al., 2011; Rosell et al., 2016) and toward sustainable solutions, the fortification with milling by-products has largely been proposed (Katina et al., 2012; Rizzello et al., 2012; Singh et al., 2012; Pontonio et al., 2017). Bran, the outer layers of cereal grains, is rich in dietary fiber as well as other bioactive compounds and germ is usually characterized by a high nutritional value (Katina et al., 2012). However, despite to the positive effects on health, the presence of high content of fiber in bran and lipase and lipoxygenase activities in germ may negatively affect the baked goods quality. Indeed, use of native bran in wheat baking is a technological challenge because of the detrimental effect of bran on the gluten network and subsequent textural attributes of bread (Noort et al., 2010) other than negative influence on the taste of the products. While, the lipase and lipoxygenase activities determine the poor and unstable sensory properties of baked goods made of wheat flour containing the germ (Paradiso et al., 2008). However, lipases are sometimes used in bakery industry as emulsifiers to increase the bread volume, soften the crumb as well as retarding bread staling (Frauenlob et al., 2018). Thermal treatments can be used to inactivate the enzymes, however, collateral negative effects on the bioactive compounds, i.e., destruction of essential fatty acids and vitamins are often highlighted (Sjovall et al., 2000). Therefore, a careful selection of process to pre-treat milling by-products need to be done. Lactic acid bacteria (LAB) have already been proposed as a promising tool to overcome the sensory, structural, functional and nutritional drawbacks related to their use as ingredients in bread-making (Katina et al., 2012; Rizzello et al., 2012; Pontonio et al., 2017).

Maize (Zea mays) is a domesticated grass that originated in what is now Mexico. Worldwide, $60-70 \%$ of maize production is used domestically as livestock feed, and the remaining 30$40 \%$ is used for production of items for human consumption (Pranjal et al., 2017). Nevertheless, due to the processing wastes and the preparation of non-food products, the use of these cereals is lower than what estimated (Ranum et al., 2014). Milling byproducts (bran and germ), which contain most of the bioactive compounds, are often removed from the kernel prior processing thus causing a loss of nutritional quality (Ranum et al., 2014).
In this study, selected LAB were used to ferment raw- and heat-treated milling by-products from maize, investigating the effects of the fermentation on their stabilization biochemical and nutritional properties. Based on the above considerations and aiming at increasing the fiber content of wheat bread valorizing food processing wastes, fermented and unfermented mixtures of maize germ and bran were used as ingredients to fortify wheat breads, evaluating biochemical and nutritional characteristics, structural properties and sensory profiles.

\section{MATERIALS AND METHODS}

\section{Bacterial Strains, Growth Conditions and Starter Selection}

Aiming at investigating a wide microbial diversity, starters were selected among 100 LAB strains (Supplementary Table S1) previously isolated from matrices with different chemical composition and sharing either most of the functional compounds and anti-nutritional factors with maize milling by-products. In detail, LAB strains belonging to the Culture Collection of the Department of Soil, Plant and Food Science (University of Bari, Italy) were previously isolated from raw or spontaneously fermented wheat, quinoa, hemp, hop, and wheat germ (Rizzello et al., 2010, 2016; Nionelli et al., 2014, 2018a,b; Pontonio et al., 2015; Mamhoud et al., 2016) (Supplementary Table S1). Strains were routinely cultivated on modified de Man, Rogosa and Sharpe medium (mMRS, maltose and fresh yeast extract were added to MRS at 1 and 5\%, respectively, and the final $\mathrm{pH}$ was 5.6) until the late exponential phase of growth was reached ( $c a .8 \mathrm{~h}$ ), as previously determined by the analysis of the kinetics of growth (Rizzello et al., 2010, 2016; Nionelli et al., 2014, 2018a,b; Pontonio et al., 2015; Mamhoud et al., 2016).

Aiming at selecting strains to be used as mixed starter for maize milling by-products fermentation, the pro-technological and functional features of LAB were evaluated when singly inoculated in their own isolation matrix (wheat, quinoa, hemp and hop flours and wheat germ). Cells were harvested by centrifugation $\left(10,000 \times \mathrm{g}, 10 \mathrm{~min}, 4^{\circ} \mathrm{C}\right)$, washed twice in $50 \mathrm{mM}$ phosphate buffer, $\mathrm{pH} 7.0$, and re-suspended in tap water. The DY (dough yield, dough weight $\times 100 /$ flour weight) was 200 and the initial cell density of each LAB was ca. $7.0 \log 10 \mathrm{cfu} / \mathrm{g}$. Fermentation was carried out in triplicate at $30^{\circ} \mathrm{C}$ for $24 \mathrm{~h}$. After fermentation, samples were stored at $4^{\circ} \mathrm{C}$ and analyzed within 2 h. Non-inoculated doughs were used as controls. Proteolytic by means of total free amino acids (TFAA), phytase and radical scavenging (in the methanolic extract) activities were considered as functional features, however, kinetics of growth and acidification were considered as pro-technological traits.

Kinetics of growth and acidification were determined and modeled in agreement with the Gompertz equation, as modified by Zwietering et al. (1990): $y=k+A \exp \{-\exp [(\mu \max$ or $\operatorname{Vmax} \mathrm{e} / \mathrm{A})(\lambda-\mathrm{t})+1]\}$; where $\mathrm{y}$ is the growth expressed as $\log 10 \mathrm{cfu} / \mathrm{g} / \mathrm{h}$ or the acidification rate expressed as $\mathrm{dpH} / \mathrm{dt}$ (units of $\mathrm{pH} / \mathrm{h}$ ) at the time $t ; k$ is the initial level of the dependent variable to be modeled ( $\log 10 \mathrm{cfu} / \mathrm{g}$ or $\mathrm{pH}$ units); $\mathrm{A}$ is the cell density or $\mathrm{pH}$ (units) variation (between inoculation and the 
stationary phase); $\mu \max$ or $\mathrm{Vmax}$ is the maximum growth rate expressed as $\Delta \log 10 \mathrm{cfu} / \mathrm{g} / \mathrm{h}$ or the maximum acidification rate expressed as $\mathrm{dpH} / \mathrm{h}$, respectively; $\lambda$ is the length of the lag phase measured in hours. The experimental data were modeled by the non-linear regression procedure of the Statistica 12.0 software (Statsoft, Tulsa, OK, United States). The values of $\mathrm{pH}$ of doughs were determined by a M.507 pHmeter (Crimson, Milan, Italy) equipped with a food penetration probe.

Water/salt-soluble extracts (WSE) from doughs were prepared according to the method originally described by Osborne (1907) and modified by Weiss et al. (1993). Briefly, $5 \mathrm{~g}$ of sample were suspended in $10 \mathrm{ml}$ of $50 \mathrm{mM}$ Tris- $\mathrm{HCl}$ ( $\mathrm{pH} 8.8$ ), incubated at $4^{\circ} \mathrm{C}$ for $1 \mathrm{~h}$ under stirring conditions (150 rpm) and centrifuged at $12,000 \times g$ for $20 \mathrm{~min}$. The supernatant was used for the determination of TFAA concentration and phytase activity. TFAA were analyzed by a Biochrom 30 series Amino Acid Analyzer (Biochrom Ltd., Cambridge Science Park, United Kingdom) with a Na-cation-exchange column (20 by $0.46 \mathrm{~cm}$ internal diameter), as described by Rizzello et al. (2010). Phytase activity was determined by monitoring the rate of hydrolysis of $p$-nitrophenyl phosphate (p-NPP) (Sigma, 104-0). The assay mixture contained $200 \mu \mathrm{L}$ of $1.5 \mathrm{mM} p$-NPP (final concentration) in $0.2 \mathrm{M} \mathrm{Na}$-acetate, $\mathrm{pH} 5.2$, and $400 \mu \mathrm{L}$ of WSE. The mixture was incubated at $45^{\circ} \mathrm{C}$ and the reaction was stopped by adding $600 \mu \mathrm{L}$ of $0.1 \mathrm{M} \mathrm{NaOH}$. The $p$-nitrophenol released was determined by measuring the absorbance at $405 \mathrm{~nm}$ (Rizzello et al., 2010). One unit (U) of activity was defined as the amount of enzyme required to liberate $1 \mu \mathrm{mol} / \mathrm{min}$ of $p$-nitrophenol under the assay conditions. The radical scavenging activity was determined on the ME methanolic extract (ME) of doughs. Three grams of each sample were mixed with $30 \mathrm{ml}$ of $80 \%$ (vol/vol) methanol to get ME. The mixture was purged with nitrogen stream for $30 \mathrm{~min}$, under stirring condition, and centrifuged at 4,600 $\times g$ for $20 \mathrm{~min}$. The supernatants (MEs) were transferred into test tubes, purged with nitrogen stream and stored at $c a .4^{\circ} \mathrm{C}$ before analysis. The radical $\mathrm{DPPH} \cdot$ was used for determining the free radical scavenging activity (Rizzello et al., 2010). The synthetic antioxidant butylated hydroxytoluene (BHT) was included in the analysis as the reference (75 ppm). The reaction was monitored by reading the absorbance at $517 \mathrm{~nm}$.

Based on the results collected under the above conditions, the two best performing strains, Lactobacillus plantarum T6B10 and Weissella confusa BAN8, were selected and used as a mixed starter for sourdough fermentation of maize milling by-products.

\section{Microbiological and Chemical Analysis of Milling By-Products}

Commercial samples of maize milling by-products, certified for mycotoxins levels (aflatoxins, zearalenone, deoxynivalenol, ochratoxin A, and fumonisin) under the thresholds defined by Reg. UE 1881/2006, Reg. UE 1126/2007, and Reg. UE 165/2010, were supplied by Molino Favero (Padova, Italy). Raw germ (RG), germ stabilized by heat-treatment (TG) and bran (B) were used in this study. The heat-treatment was carried out at $c a$. $200^{\circ} \mathrm{C}$ until the product temperature of $110^{\circ} \mathrm{C}$ was achieved. Temperature was monitored during treatment trough an RTD temperature probe (Jumo Food temp insertion RTD 902350, Sesto San Giovanni, Italy). Proximal analysis of the milling byproducts prior doughs preparation was carried out.

Protein (total nitrogen $\times 5.7$ ), lipids, moisture, total dietary fiber and ash of RG, TG and B were determined according to Approved Methods 46-11A, 30-10.01, 44-15A, 32-05.01, and 08-01.01 of the American Association of Cereal Chemists (American Association of Cereal Chemists [AACC], 2010). Available carbohydrates were calculated as the difference $[100-$ (proteins + lipids + ash + total dietary fiber) $]$. Proteins, lipids, carbohydrates, total dietary fiber and ash were expressed as $\%$ of dry matter (d.m.).

Microbiological analyses were carried out on milling byproducts as specified below. In details, $10 \mathrm{~g}$ of RG, TG and B were suspended in $90 \mathrm{ml}$ of sterile sodium chloride $(0.9 \%$, $\mathrm{wt} / \mathrm{vol}$ ) solution and homogenized in a Stomacher lab blender for $2 \mathrm{~min}$ at room temperature. Mesophilic presumptive LAB were determined on mMRS at $30^{\circ} \mathrm{C}$ for $48-72 \mathrm{~h}$, under anaerobiosis. Yeasts were plated on Sabouraud Dextrose Agar (SDA, Oxoid, Basingstoke, Hampshire, United Kingdom), supplemented with chloramphenicol $(0.1 \mathrm{~g} / \mathrm{l})$ at $25^{\circ} \mathrm{C}$ for $48 \mathrm{~h}$. Molds were enumerated on Potato Dextrose Agar (PDA, Oxoid) at $25^{\circ} \mathrm{C}$ for 48 h. Total Enterobacteria were determined on Violet Red Bile Glucose Agar (VRBGA, Oxoid) at $37^{\circ} \mathrm{C}$ for $24 \mathrm{~h}$ and total mesophilic bacteria were determined on Plate Count Agar (PCA, Oxoid) at $30^{\circ} \mathrm{C}$ for $48 \mathrm{~h}$.

\section{Milling By-Products Fermentation}

Doughs (100 g) consisting of milling by-products mixtures and water (1:1) were obtained by an IM 58 high-speed mixer (Mecnosud, Flumeri, Italy). DY was 200. Mixtures of RG and $\mathrm{B}$ (ratio 2:1, $\mathrm{FMBP}_{\mathrm{RG}}$ ) or TG and $\mathrm{B}$ (ratio 2:1, $\mathrm{FMBP}_{\mathrm{TG}}$ ) were used. Doughs were inoculated with L. plantarum T6B10 and $W$. confusa BAN8 each at the cell density of $c a .7 \log 10 \mathrm{cfu} / \mathrm{g}$ of dough. Fermentations were carried out in triplicate at $30^{\circ} \mathrm{C}$ for $24 \mathrm{~h}$. After fermentation, samples were stored at $4^{\circ} \mathrm{C}$ and analyzed within $2 \mathrm{~h}$. Non-fermented doughs $\left(\mathrm{MBP}_{\mathrm{RG}}\right.$ and $\mathrm{MBP}_{\mathrm{TG}}$ ) were used as controls.

\section{Microbiological, Biochemical and Nutritional Characterization of Fermented Milling By-Products}

Lactic acid bacteria and $\mathrm{pH}$ values of $\mathrm{MBP}_{\mathrm{RG}}, \mathrm{MBP}_{\mathrm{TG}}, \mathrm{FMBP}_{\mathrm{RG}}$, and $\mathrm{FMB}_{\mathrm{TG}}$ were determined as reported above. Ten grams of $\mathrm{MBP}_{\mathrm{RG}}, \mathrm{MBP}_{\mathrm{TG}}, \mathrm{FMBP}_{\mathrm{RG}}$, and $\mathrm{FMB}_{\mathrm{TG}}$ were homogenized with $90 \mathrm{ml}$ of distilled water for the determination of total titratable acidity (TTA). TTA is expressed as the amount ( $\mathrm{ml}$ ) of $0.1 \mathrm{M} \mathrm{NaOH}$ to reach $\mathrm{pH}$ of 8.3. WSE from fermented and unfermented doughs were used for the determination of organic acids, peptides, TFAA concentrations and radical scavenging activity. Organic acids were determined by High Performance Liquid Chromatography (HPLC), using an ÄKTA Purifier system (GE Healthcare, Buckinghamshire, United Kingdom) equipped with an Aminex HPX-87H column (ion exclusion, Bio-Rad, Richmond, CA, United States), and an UV detector operating at $210 \mathrm{~nm}$. Elution was at $60^{\circ} \mathrm{C}$, with a flow rate of $0.6 \mathrm{ml} / \mathrm{min}$, 
using $\mathrm{H}_{2} \mathrm{SO}_{4} 10 \mathrm{mM}$ as mobile phase (Rizzello et al., 2010). The quotient of fermentation (QF) was determined as the molar ratio between lactic and acetic acids. TFAA were analyzed as reported above. For the peptides analysis, WSE were treated with trifluoroacetic acid ( $0.05 \% \mathrm{wt} / \mathrm{vol})$ and subject to dialysis (cut-off $500 \mathrm{Da}$ ) to remove proteins and FAA, respectively. Then, peptides concentration was determined by the $o$-phtaldialdehyde (OPA) method as described by Church et al. (1983). All analyses were carried out in triplicate.

Tributyrin was used as the substrate to determine the lipase activity of the $\mathrm{MBP}_{\mathrm{RG}}, \mathrm{MBP}_{\mathrm{TG}}, \mathrm{FMBP}_{\mathrm{RG}}$, and $\mathrm{FMBP}_{\mathrm{TG}}$ extract by agar diffusion assay (Lawrence et al., 1967). Agar plates contained $1 \%(\mathrm{wt} / \mathrm{vol})$ of triglyceride, $0.02 \%(\mathrm{wt} / \mathrm{vol})$ sodium azide, and $50 \mathrm{mM}$ phosphate buffer, $\mathrm{pH}$ 8.0. As reported by Lin et al. (1983), this value of $\mathrm{pH}$ was the optimum for maize germ endogenous lipase activity. Activity was expressed as the minimum dilution of the enzyme preparation that failed to give a detectable zone of hydrolysis after $24 \mathrm{~h}$ of incubation at $30^{\circ} \mathrm{C}$.

Phytic acid concentration was measured using K-PHYT 05/07 kit assay (Megazyme Intl., Ireland), following the manufacturer's instructions. Total phenols and radical scavenging activity were determined on the $\mathrm{ME}$ of $\mathrm{MBP}_{\mathrm{RG}}, \mathrm{MBP}_{\mathrm{TG}}, \mathrm{FMBP}_{\mathrm{RG}}$, and FMBP $_{\mathrm{TG}}$. The concentration was determined as described by Slinkard and Singleton (1977) and expressed as gallic acid equivalent. The radical scavenging activity was determined as reported above.

\section{Breadmaking}

Experimental breads (DY, 180) were manufactured at the pilot plant of the Department of Soil, Plant and Food Science of the University of Bari (Italy), according to the two-stage protocol commonly used for sourdough breadmaking (Rizzello et al., 2016). $\mathrm{MBP}_{\mathrm{RG}}$ and $\mathrm{MBP}_{\mathrm{TG}}$ were fermented at $30^{\circ} \mathrm{C}$ for $24 \mathrm{~h}$ with the mixed starters as described before (step I); then, FMBP RG $_{\text {and }}$ $\mathrm{FMBP}_{\mathrm{TG}}$ were mixed with wheat flour, water, and baker's yeast at $60 \times g$ for 5 min with an IM 58 high-speed mixer (Mecnosud, Flumeri, Italy) and incubated for $1.5 \mathrm{~h}$ at $30^{\circ} \mathrm{C}$ (step II). The characteristics of the flour (Triticum aestivum, cv Appulo) used were the following: moisture, $14.2 \%$; protein $(\mathrm{N} \times 5.70), 11.5 \%$ of d.m.; fat, $1.6 \%$ of d.m.; ash, $0.6 \%$ of d.m. and total soluble carbohydrates, $1.5 \%$ of d.m. In detail, $\mathrm{MBP}_{\mathrm{RG}}$ and $\mathrm{MBP}_{\mathrm{TG}}$ and FMBP $_{\mathrm{RG}}$ and $\mathrm{FMBP}_{\mathrm{TG}}$ were used at the percentage of 12.5 and $25 \%$ (wt/wt), respectively, of the total dough weight (Nionelli et al., 2014). At the end of step II, doughs (300 g) were baked at $220^{\circ} \mathrm{C}$ for $50 \mathrm{~min}$ (Combo 3, Zucchelli, Verona, Italy), obtaining breads fortified with raw and fermented milling by-products $\left(\mathrm{MBP}_{\mathrm{RG}}-\mathrm{B} / \mathrm{MBP}_{\mathrm{TG}}-\mathrm{B}\right.$ and $\mathrm{FMBP} \mathrm{RG}-\mathrm{B} / \mathrm{FMBP}_{\mathrm{TG}}-\mathrm{B}$, respectively). A baker's yeast wheat bread (WB) was manufactured without the addition of milling by-products (DY, 180) and used as the control. Baker's yeast was added at the percentage of $1.5 \%$ (wt/wt), corresponding to a final cell density of $\mathrm{ca} .9 \mathrm{log} 10 \mathrm{cfu} / \mathrm{g}$ in all the doughs only for the step II. Salt was not used. All breads were cooled for a period of $2 \mathrm{~h}$ on cooling racks at room temperature prior analysis.

The Texture Profile Analysis (TPA) of bread was carried out by means of a Universal Testing machine (model 3344, Instron, Norwood, MA, United States), equipped with $3.6 \mathrm{~cm}$ diameter cylindrical probe, $1000 \mathrm{~N}$ load cell. The chromaticity co-ordinates of the bread crust (obtained by a Minolta CR-10 camera) were also reported in the form of a color difference, $\mathrm{dE}^{*} \mathrm{ab}$, as follows:

$$
d E^{*} a b=\sqrt{(\mathrm{d} L)^{2}+(\mathrm{d} a)^{2}+(\mathrm{d} b)^{2}}
$$

where $\mathrm{dL}, \mathrm{da}$, and $\mathrm{db}$ are the differences for $L, a$, and $b$ values between sample and reference a white ceramic plate having $L=67.04, a=2.44$, and $b=18.28$.

The values of $\mathrm{pH}$ and TTA, concentration of organic acids, TFAA, total phenols and phytic acid and radical scavenging activity were determined as reported above. The specific volume and moisture content of breads were measured determined according to the approved methods AACC 10-05.01 and 4415.02, respectively (American Association of Cereal Chemists [AACC], 2010). Water activity $\left(a_{\mathrm{W}}\right)$ was determined at $25^{\circ} \mathrm{C}$ by the Aqualab Dew Point 4TE water activity meter (Decagon Devices Inc., United States). Fermentations were carried out in triplicate and each bread was analyzed twice.

\section{Nutritional Characterization of Breads}

The in vitro protein digestibility (IVPD) of breads was determined by the method proposed by Akeson and Stahmann (1964) with some modifications (Rizzello et al., 2014). Samples were subjected to a sequential enzyme treatment mimicking the in vivo digestion in the gastro intestinal tract and IVPD was expressed as the percentage of the total protein which was solubilized after enzyme hydrolysis. The concentration of protein of digested and non-digested fractions was determined by the Bradford method (Bradford, 1976). The analysis of starch hydrolysis was carried out on breads. The procedure mimicked the in vivo digestion of starch (De Angelis et al., 2009). Aliquots of breads, containing $1 \mathrm{~g}$ of starch, were undergo to enzymatic process and the released glucose content was measured with D-Fructose/D-Glucose Assay Kit (Megazyme). The degree of starch digestion was expressed as the percentage of potentially available starch hydrolyzed after $180 \mathrm{~min}$. Wheat flour bread (WB) leavened with baker's yeast was used as the control to estimate the hydrolysis index $(\mathrm{HI}=100)$. The predicted GI was calculated using the equation: $\mathrm{GI}=0.549 \times \mathrm{HI}+39.71$ (Capriles and Areas, 2013).

\section{Sensory Analysis}

Sensory analysis of breads was carried out by 10 trained panelists ( 5 male and 5 females, mean age: 35 years, range: 18-54 years), according to the method described by Haglund et al. (1998). After a roundtable discussion about the attributes, 13 were selected as the most frequently recognized by all the members of the panel. These were included in a score sheet for the quantitative evaluation with a scale from 0 to 10 , with 10 the highest score. Elasticity of crumb, softness of crumb, crust and crumb color were considered visual/kinesthetic attributes Taste was evaluated as nuts, sourness, bitterness and toasted, while for aroma was evaluated the intensity, the rancid and aromatic characteristics of mixed nuts (Georgsson, 2015). Besides, the typical aroma of a fermented 
dough was evaluated. According to the IFST Guidelines for Ethical and Professional Practices for the Sensory Analysis of Foods, assessors gave informed consent to tests and could withdraw from the panel at any time, without penalty or having to give a reason.

\section{Statistical Analysis}

Data were subjected to one-way ANOVA; pair-comparison of treatment means was achieved by Tukey's procedure at $P<0.05$, using the statistical software, Statistica 12.5 (TIBCO Software Inc., Palo Alto, CA, United States) for Windows. Principal Components analysis was performed through Xlstat 2014 (Addinsoft, New York, NY, United States).

\section{RESULTS}

\section{Starters Selection for Lactic Acid Fermentation}

Lactic acid bacteria strains were singly used to ferment wheat, quinoa, hemp and hop flours and wheat germ at $30^{\circ} \mathrm{C}$ for $24 \mathrm{~h}$. To allow the comparison between results from different food matrices, the increase (\%) of TFAA concentration and phytase and radical scavenging activities, as compared to the corresponding non-inoculated doughs, were considered (Figure 1A). Increases of TFAA were in the range $13-87 \%$, being the highest for $L$. plantarum T6B10 and the lowest for Lactobacillus farciminis S3N2. Similarly, wide increase of the phytase activity was found among the LAB strains, with highest and lowest values reached when L. plantarum T6B10 (81.7\%) and Lactococcus lactis LVS $26(3.8 \%)$ were used, respectively. Highest value of radical scavenging activity (44.3\%) were found when L. plantarum LIN 2 was used to ferment wheat flour (Figure 1A). According to the pro-technological features, $W$. confusa BAN8 showed highest cell density increase $\left(\mathrm{A}_{\mathrm{G}}, 2.4 \log 10 \mathrm{cfu} / \mathrm{g}\right)$. Moreover, both L. plantarum $\mathrm{T} 6 \mathrm{~B} 10$ and $W$. confusa BAN8 fell into the 75 and $25 \%$ percentile of the $A_{\mathrm{A}}$ and $\lambda_{\mathrm{A}}$ and $\lambda_{\mathrm{G}}$, respectively (Figure 1B).

Based on the above results, L. plantarum $\mathrm{T} 6 \mathrm{~B} 10$ and $W$. confusa BAN were selected and used as mixed starter to ferment maize milling by-products.

\section{Milling By-Products Characterization}

The proximal composition and microbiological characterization of RG, TG and B used in this study are reported in Table $\mathbf{1 .}$ The heat-treatment led to a TG having moisture four times lower than RG. Although B was also subjected to heat-treatment, its moisture was $10.6 \pm 0.9 \%$. As expected, RG and TG contained high level of fat (up to ca. 33\% of d.m.) and B was characterized by the highest concentration of carbohydrates and especially total dietary fiber (up to ca. 50\%). Probably due to the heat treatment, any of the microbial groups investigated were detectable in $1 \mathrm{~g}$ TG, however, total mesophilic bacteria and molds were detected in $\mathrm{B}$ at cell density $\leq 2$ $\log 10 \mathrm{cfu} / \mathrm{g}$ (Table 1).

\section{Fermented Milling By-Products Characterization}

Either $\mathrm{RG}$ or $\mathrm{TG}$ and $\mathrm{B}\left(\mathrm{MBP}_{\mathrm{RG}}\right.$ and $\mathrm{MBP}_{\mathrm{TG}}$, respectively) were mixed before use in a ratio 2 ( $R G$ or $T G$ ) to 1 (B). $\mathrm{MBP}_{\mathrm{RG}}$ and $\mathrm{MBP}_{\mathrm{TG}}$ had similar values of $\mathrm{pH}$ and TTA, being ca. 6.3 and $9 \mathrm{ml} \mathrm{NaOH} 0.1 \mathrm{M}$, respectively (Table 2). However, the concentration of lactic acid was significantly higher in $M B P_{R G}$. Acetic acid was not detectable in any of the sample prior the fermentation. Significant differences were also found for TFAA and peptides concentrations, being higher in $\mathrm{MBP}_{\mathrm{RG}}$ (Table 2). As expected, after $24 \mathrm{~h}$ of fermentation with $L$. plantarum $\mathrm{T} 6 \mathrm{~B} 10$ and $W$. confusa BAN8, the value of $\mathrm{pH}$ of FMBP $_{\mathrm{RG}}$ and $\mathrm{FMBP}_{\mathrm{TG}}$ was lower compared to the corresponding unfermented doughs $\left(\mathrm{MBP}_{\mathrm{RG}}\right.$ and $\mathrm{MBP}_{\mathrm{TG}}$, respectively), with lower value in $\mathrm{FMBP}_{\mathrm{TG}}$. On the contrary, values of TTA increased during fermentation, being significantly higher in $\mathrm{FMBP}_{\mathrm{TG}}$ compared to $\mathrm{FMBP}_{\mathrm{RG}}$. Lactic acid concentration in $\mathrm{FMBP}_{\mathrm{RG}}$ and $\mathrm{FMBP}_{\mathrm{TG}}$ was $c a$. 10-100 times higher than $\mathrm{MBP}_{\mathrm{RG}}$ and $\mathrm{MBP}_{\mathrm{TG}}$, respectively (Table 2). Similar trend was found for acetic acid. Moreover, FMBP $_{\mathrm{RG}}$ and $\mathrm{FMBP}_{\mathrm{TG}}$ contained different concentrations of both lactic and acetic acids, being higher in $\mathrm{FMBP}_{\mathrm{TG}}$ and $\mathrm{FMBP}_{\mathrm{RG}}$, respectively. QF was determined only in the fermented samples, being ca. 4.7. Fermented samples $\left(\mathrm{FMBP}_{\mathrm{RG}}\right.$ and $\mathrm{FMBP}_{\mathrm{TG}}$ ) had significantly higher concentrations of TFAA (up to $80 \%$ ) and peptides (up to $21 \%$ ) compared to $\mathrm{MBP}_{\mathrm{RG}}$ and $\mathrm{MBP}_{\mathrm{TG}}$. Moreover, the presence of raw germ in the mixture $\left(\mathrm{MBP}_{\mathrm{RG}}\right.$ and $\left.\mathrm{FMBP}_{\mathrm{RG}}\right)$ led to higher values compared to heat-treated germ containing samples $\left(\mathrm{MBP}_{\mathrm{TG}}\right.$ and $\left.\mathrm{FMBP}_{\mathrm{TG}}\right)$. As regard to the nutritional properties, $\mathrm{MBP}_{\mathrm{RG}}$ contained higher contents of phytic acids as compared to $\mathrm{MBP}_{\mathrm{TG}}$, however, any significant differences were found in term of total phenols. Moreover, the radical scavenging activity in the WSE, was lower in $\mathrm{MBP}_{\mathrm{RG}}$. The fermentation led to a decrease and increase of the phytic acid concentration (up to 50\%) and radical scavenging activity in the WSE (up to 30 times), respectively (Table 2). A slight increase of the concentration of total phenols was also found (Table 2). The minimum concentration of the crude enzyme extract that failed to give a detectable zone of hydrolysis was $35 \pm 2.7 \mu \mathrm{g} / \mathrm{ml}$ for $\mathrm{MBP}_{\mathrm{RG}}$.

\section{Biochemical and Nutritional Characterization of Breads}

Biochemical and nutritional characteristics of breads are summarized in Table 3. Similar values of moisture and $a_{\mathrm{w}}$ were found between breads $\left(\mathrm{MBP}_{\mathrm{RG}}-\mathrm{B}, \mathrm{MBP}_{\mathrm{TG}}-\mathrm{B}, \mathrm{FMBP}_{\mathrm{RG}}-\mathrm{B}\right.$, and $\left.\mathrm{FMBP}_{\mathrm{TG}}-\mathrm{B}\right)$. No significant differences were found between enriched breads and WB (Table 3). As expected, the values of $\mathrm{pH}$, TTA and concentrations of lactic and acetic acids (up to 6 times) were lower and higher, respectively, in breads enriched with fermented milling by-products $\left(\mathrm{FMBP}_{\mathrm{RG}}-\mathrm{B}\right.$ and $\left.\mathrm{FMBP}_{\mathrm{TG}}-\mathrm{B}\right)$ as compared to $\mathrm{MBP}_{\mathrm{RG}}-\mathrm{B}, \mathrm{MBP}_{\mathrm{TG}}-\mathrm{B}$, and $\mathrm{WB}$. Moreover, $\mathrm{MBP}_{\mathrm{RG}}-\mathrm{B}$ was characterized by higher value of $\mathrm{pH}$ and concentrations of lactic and acetic acids as compared to $\mathrm{MBP}_{\mathrm{TG}}-\mathrm{B}$, however, the TTA did not differ significantly. Any significant differences were found in term of acetic acids between in $\mathrm{FMBP}_{\mathrm{RG}}-\mathrm{B}$ and $\mathrm{FMBP}_{\mathrm{TG}}-\mathrm{B}$. According to these results, the 
A

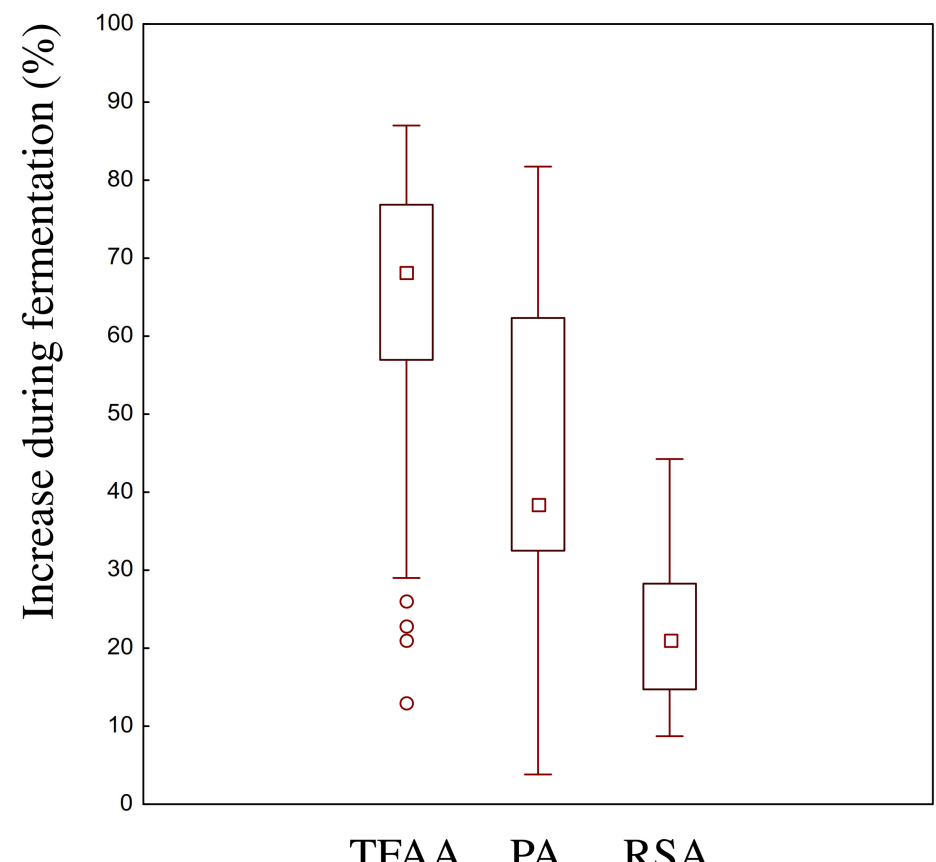

B

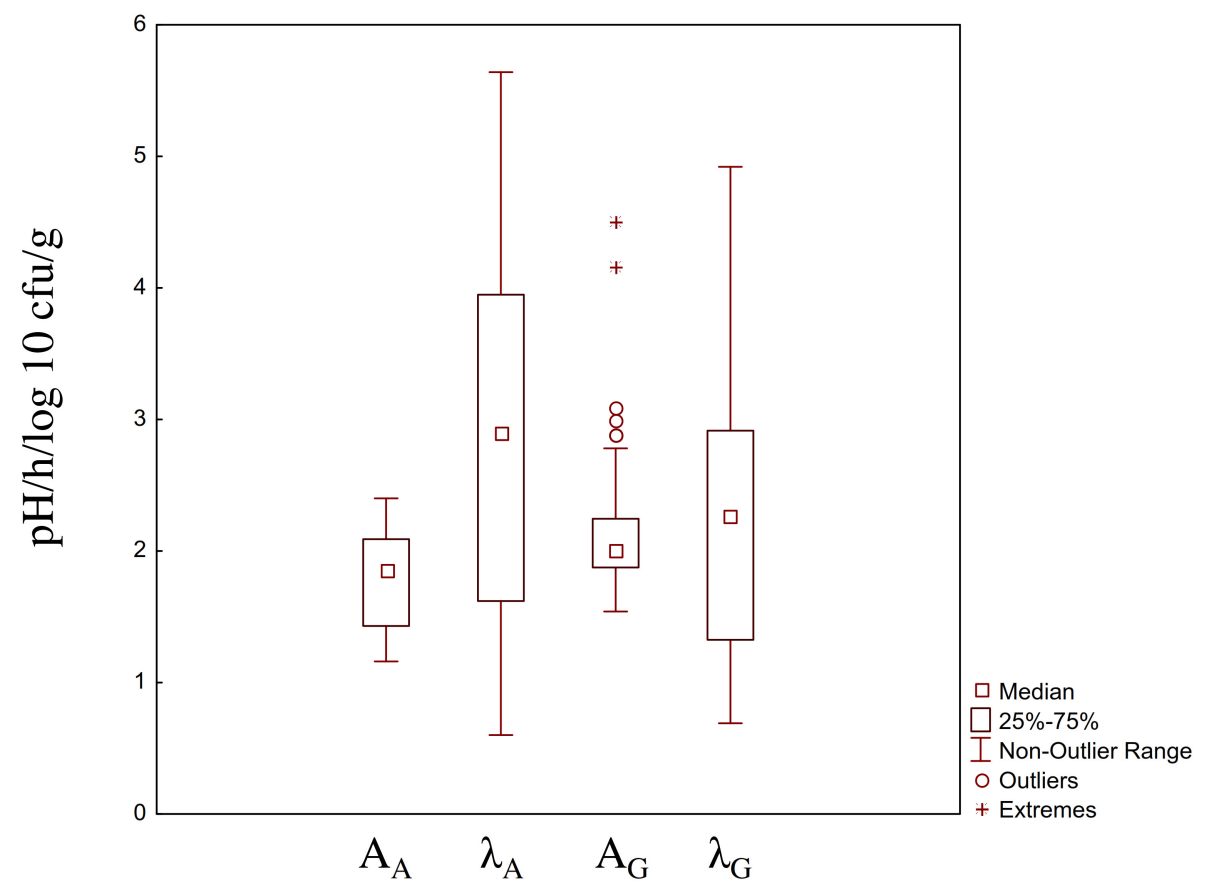

FIGURE 1 | Boxplot showing the functional (A) and pro-technological (B) characterization of 100 strains of lactic acid bacteria belonging to the species Lactobacillus brevis, Lactobacillus curvatus, Lactobacillus helveticus, Lactobacillus farciminis, Lactobacillus nantensis, Lactobacillus plantarum, Lactobacillus rossiae, Lactococcus lactis, Pediococcus acidilactici, Pediococcus pentosaceus, Weissella cibaria, Weissella confusa, Leuconostoc citreum, and Leuconostoc mesenteroides of the Culture Collection of the Department of Soil, Plant and Food Science of the University of Bari, Italy and isolated from raw or spontaneously fermented wheat, hemp, hop, quinoa, wheat germ and bran. The increase (\%) of TFAA concentration, phytase (PA) and radical scavenging (RSA) activities in wheat, hemp, hop, quinoa, wheat germ and bran (DY 200) singly inoculated with the strains and fermented for $24 \mathrm{~h}$ at $30^{\circ} \mathrm{C}$, compared to a not inoculated dough incubated in the same conditions were considered as functional features. Panel $B$ displays the boxplot of the acidification $\left(A_{A}, p H ; \lambda_{A}, h\right)$ and growth $\left(A_{G}\right.$, log $10 \mathrm{cfu} / \mathrm{g} ; \lambda_{G}$, h) kinetics parameters of the strains in the above-mentioned conditions, respectively. The top and the bottom of the box represent the 75th and 25th percentile of the data, respectively. The top and the bottom of the bars represent the 5th and the 95th percentile of the data, respectively. 
TABLE 1 | Proximal composition and microbiological characterization of the maize raw (RG) and heat-treated (TG) germ and bran (B).

\begin{tabular}{|c|c|c|c|}
\hline & $\mathbf{R G}$ & TG & B \\
\hline \multicolumn{4}{|l|}{ Proximal composition* } \\
\hline Moisture (\%) & $7.9 \pm 0.3^{b}$ & $2.3 \pm 0.2^{a}$ & $10.6 \pm 0.9^{c}$ \\
\hline Protein (\%) & $21.9 \pm 0.2^{b}$ & $19.8 \pm 0.2^{a}$ & $18.4 \pm 0.6^{a}$ \\
\hline Fat (\%) & $32.3 \pm 0.3^{b}$ & $33.5 \pm 0.8^{c}$ & $3.2 \pm 0.1^{a}$ \\
\hline Available carbohydrates (\%) & $9.5 \pm 0.9^{b}$ & $5.7 \pm 0.9^{a}$ & $23.3 \pm 0.9^{c}$ \\
\hline Total dietary fibers (\%) & $32.7 \pm 0.8^{a}$ & $32.7 \pm 0.4^{a}$ & $50.0 \pm 0.8^{b}$ \\
\hline Ash (\%) & $8.2 \pm 0.4^{b}$ & $8.3 \pm 0.6^{b}$ & $5.0 \pm 0.2^{a}$ \\
\hline \multicolumn{4}{|l|}{ Microbiological characterization } \\
\hline Mesophilic aerobic bacteria $(\log 10$ cfu/g) & $5.3 \pm 0.7^{c}$ & $<10 \mathrm{cfu} / 1 \mathrm{~g}^{\mathrm{a}}$ & $2.0 \pm 0.3^{b}$ \\
\hline Yeast (log10 cfu/g) & $<10 \mathrm{cfu} / 1 \mathrm{~g}^{\mathrm{a}}$ & $<10 \mathrm{cfu} / 1 \mathrm{~g}^{\mathrm{a}}$ & $<10 \mathrm{cfu} / 1 \mathrm{~g}^{\mathrm{a}}$ \\
\hline Molds (log10 cfu/g) & $4.3 \pm 0.6^{c}$ & $<10 \mathrm{cfu} / 1 \mathrm{~g}^{\mathrm{a}}$ & $1.5 \pm 0.2^{b}$ \\
\hline LAB (log10 cfu/g) & $3.5 \pm 0.5^{b}$ & $<10 \mathrm{cfu} / 1 \mathrm{~g}^{\mathrm{a}}$ & $<10 \mathrm{cfu} / 1 \mathrm{~g}^{\mathrm{a}}$ \\
\hline Enterobacteriaceae (log10 cfu/g) & $2.0 \pm 0.3^{b}$ & $<10 \mathrm{cfu} / 1 \mathrm{~g}^{\mathrm{a}}$ & $<10 \mathrm{cfu} / 1 \mathrm{~g}^{\mathrm{a}}$ \\
\hline
\end{tabular}

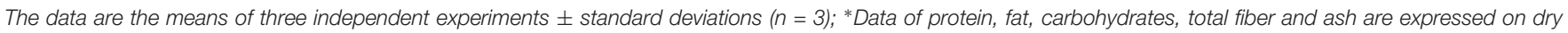
weight; $L A B$, Lactic acid bacteria; ${ }^{a-c}$ Values in the same row with different superscript letters differ significantly ( $\left.p<0.05\right)$.

TABLE 2 | Biochemical and nutritional properties of maize milling by-products doughs: MBP $\mathrm{RG}$, unfermented mixture of raw germ and bran; MBPTG, unfermented mixture of heat-treated germ and bran; FMBP ${ }_{\mathrm{RG}}$ fermented mixture of raw germ and bran; FMBPTG, fermented mixture of heat-treated germ and bran.

\begin{tabular}{|c|c|c|c|c|}
\hline & $\mathrm{MBP}_{\mathrm{RG}}$ & $\mathrm{MBP}_{\mathrm{TG}}$ & $\mathrm{FMBP}_{\mathrm{RG}}$ & FMBP $_{\text {TG }}$ \\
\hline \multicolumn{5}{|l|}{ Biochemical characteristics } \\
\hline $\mathrm{pH}$ & $6.41 \pm 0.4^{c}$ & $6.23 \pm 0.5^{c}$ & $4.21 \pm 0.02^{b}$ & $4.04 \pm 0.01^{a}$ \\
\hline TTA (ml NaOH $0.1 \mathrm{M})$ & $8.4 \pm 0.6^{a}$ & $9.6 \pm 0.5^{b}$ & $31.2 \pm 0.5^{\mathrm{c}}$ & $35.5 \pm 0.3^{d}$ \\
\hline Lactic acid (mmol/Kg) & $5.22 \pm 0.2^{b}$ & $0.70 \pm 0.4^{a}$ & $60.47 \pm 0.6^{c}$ & $66.48 \pm 0.4^{d}$ \\
\hline Acetic acid (mmol/Kg) & n.d. & n.d. & $7.0 \pm 0.6^{b}$ & $4.67 \pm 0.4^{a}$ \\
\hline QF & n.d. & n.d. & $4.0 \pm 0.2^{b}$ & $5.4 \pm 0.3^{a}$ \\
\hline TFAA (mg/Kg) & $1431 \pm 12^{b}$ & $816 \pm 15^{a}$ & $1905 \pm 14^{d}$ & $1470 \pm 20^{c}$ \\
\hline Peptide concentration (mg/g) & $38.4 \pm 0.4^{b}$ & $35.3 \pm 0.4^{a}$ & $46.5 \pm 0.6^{d}$ & $42.1 \pm 0.4^{\mathrm{c}}$ \\
\hline \multicolumn{5}{|l|}{ Nutritional characteristics } \\
\hline Phytic acid (g/100 g) & $1.10 \pm 0.03^{\mathrm{C}}$ & $0.81 \pm 0.02^{b}$ & $0.53 \pm 0.02^{a}$ & $0.55 \pm 0.04^{a}$ \\
\hline Total phenols (mmol/Kg) & $1.6 \pm 0.4^{a}$ & $1.7 \pm 0.2^{\mathrm{a}}$ & $1.8 \pm 0.4^{\mathrm{a}}$ & $2.0 \pm 0.3^{a}$ \\
\hline Radical scavenging activity (\%) on ME & $52.3 \pm 0.3^{b, c}$ & $51.3 \pm 0.7^{b}$ & $52.8 \pm 0.4^{c}$ & $50.9 \pm 0.3^{a}$ \\
\hline Radical scavenging activity (\%) on WSE & $1.4 \pm 0.04^{a}$ & $5.8 \pm 0.03^{b}$ & $42.5 \pm 0.3^{d}$ & $41.4 \pm 0.6^{c}$ \\
\hline
\end{tabular}

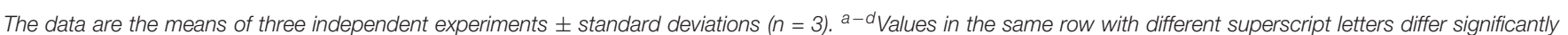

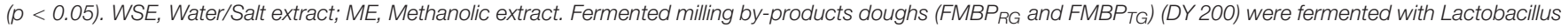
plantarum T6B10 and Weissella confusa BAN8 at $30^{\circ} \mathrm{C}$ for $24 \mathrm{~h}$.

QF was higher in fermented milling by-products containing breads. Significant higher (up to $c a .3$ times) concentrations of TFAA were found in enriched breads as compared to WB. Among experimental breads, $\mathrm{FMBP}_{\mathrm{RG}}-\mathrm{B}$ and $\mathrm{FMBP}_{\mathrm{TG}}-\mathrm{B}$ contained higher (58-91\%, respectively) concentration of TFAA as compared to the corresponding $\mathrm{MBP}_{\mathrm{RG}}-\mathrm{B}$ and $\mathrm{MBP}_{\mathrm{TG}}-\mathrm{B}$, however, $\mathrm{MBP}_{\mathrm{RG}}-\mathrm{B}$ had higher contents than $\mathrm{MBP}_{\mathrm{TG}}-\mathrm{B}$. Similar trend was found for peptides contents. Lowest content was found for WB. Higher values were found in enriched breads (24-70\%) as compared to $\mathrm{WB}$, however, the use of fermented milling byproducts led to a higher content of peptides (up to ca. 30\%) as compared to the corresponding un-fermented milling byproducts breads. Overall, the use of RG corresponded to higher values, as compared to TG (Table 3).

The higher concentrations of TFAA and peptides in breads containing the fermented milling by-products reflected on the
IVPD which was up to $70 \%$ with respect to $\mathrm{MBP}_{\mathrm{TG}}$ and $\mathrm{MBP}_{\mathrm{RG}}$ (ca. 40\%). WB had the lowest IVPD, 13-23\% and 79-84\% higher values were found for $\mathrm{MBP}_{\mathrm{RG}}-\mathrm{B}$ and $\mathrm{MBP}_{\mathrm{TG}}-\mathrm{B}$ and $\mathrm{FMBP}_{\mathrm{RG}}-\mathrm{B}$ and $\mathrm{FMBP}_{\mathrm{TG}}-\mathrm{B}$, respectively. Compared to $\mathrm{WB}$, $\mathrm{MBP}_{\mathrm{RG}}-\mathrm{B}$ and $\mathrm{MBP}_{\mathrm{TG}}-\mathrm{B}$ and $\mathrm{FMBP}_{\mathrm{RG}}-\mathrm{B}$ and $\mathrm{FMBP}_{\mathrm{TG}}-\mathrm{B}$ were characterized by significant lower values of the HI. Moreover, up to $13 \%$ lower values of the $\mathrm{HI}$ were observed in $\mathrm{FMBP}_{\mathrm{RG}}-\mathrm{B}$ and $\mathrm{FMBP}_{\mathrm{TG}}-\mathrm{B}$ as compared to the corresponding un-fermented milling by-products enriched breads. The lowest value was found for $\mathrm{FMBP}_{\mathrm{TG}} \mathrm{B}$ ( $\mathrm{ca}$. 77\%). The use of milling by-products as ingredient in breadmaking led to high fiber (up to ca. $11 \%$ of d.m) and protein of $c a$. (13\% of d.m) contents in all breads as compared to $\mathrm{WB}$, regardless the fermentation process and the germ heat-treatment.

According to the results of MBP, phytic acid content was lower in $\mathrm{MBP}_{\mathrm{TG}}-\mathrm{B}$ compared to $\mathrm{MBP}_{\mathrm{RG}}-\mathrm{B}$. Lower values were 
TABLE 3 | Biochemical and nutritional properties of breads: $\mathrm{MBP}_{\mathrm{RG}}-\mathrm{B}$, containing unfermented mixture of raw germ and bran (MBP $\mathrm{RG}, 12.5 \%$, wt/wt); $\mathrm{MBP} \mathrm{TG}_{\mathrm{T}}-\mathrm{B}$, containing unfermented mixture of heat-treated germ and bran $\left(\mathrm{MBP}_{\mathrm{TG}}, 12.5 \%\right.$, wt/wt); $\mathrm{FMBP}_{\mathrm{RG}}-\mathrm{B}$, containing fermented mixture of raw germ and bran (FMBP $\mathrm{RG}, 25 \%$ wt/wt); FMBP $\mathrm{TG}_{\mathrm{T}} \mathrm{B}$, containing fermented mixture of heat-treated germ and bran (FMBP $\left.\mathrm{TG}_{\mathrm{T}}, 25 \% \mathrm{wt} / \mathrm{wt}\right)$; wB, wheat flour bread.

\begin{tabular}{|c|c|c|c|c|c|}
\hline & $\mathrm{MBP}_{\mathrm{RG}}-\mathrm{B}$ & MBP $_{\mathrm{TG}}-\mathrm{B}$ & $\mathrm{FMBP}_{\mathrm{RG}}-\mathrm{B}$ & FMBP $_{\mathrm{TG}}-\mathrm{B}$ & WB \\
\hline \multicolumn{6}{|l|}{ Biochemical characteristics } \\
\hline Moisture (\%) & $32.9 \pm 0.3^{b}$ & $31.9 \pm 0.6^{a}$ & $32.5 \pm 0.8^{b}$ & $31.6 \pm 0.7^{a, b}$ & $31.0 \pm 0.2^{a}$ \\
\hline$a_{w}$ & $0.93 \pm 0.05^{a}$ & $0.94 \pm 0.06^{a}$ & $0.94 \pm 0.04^{a}$ & $0.94 \pm 0.06^{a}$ & $0.92 \pm 0.02^{a}$ \\
\hline $\mathrm{pH}$ & $5.59 \pm 0.05^{c}$ & $5.46 \pm 0.06^{b}$ & $4.22 \pm 0.04^{a}$ & $4.17 \pm 0.01^{a}$ & $5.61 \pm 0.3^{c}$ \\
\hline TTA (ml NaOH $0.1 \mathrm{M})$ & $8.2 \pm 0.6^{a}$ & $8.2 \pm 0.4^{a}$ & $15.4 \pm 0.4^{b}$ & $16.6 \pm 0.3^{c}$ & $9.1 \pm 0.3^{a}$ \\
\hline Lactic acid (mmol/Kg) & $1.53 \pm 0.02^{b}$ & $0.76 \pm 0.04^{a}$ & $25.1 \pm 0.6^{c}$ & $29.2 \pm 0.4^{d}$ & $3.3 \pm 0.5^{\mathrm{a}}$ \\
\hline Acetic acid (mmol/Kg) & $3.93 \pm 0.05^{b}$ & $0.83 \pm 0.03^{a}$ & $5.7 \pm 0.5^{\mathrm{c}}$ & $5.3 \pm 0.6^{c}$ & $1.27 \pm 0.3^{a}$ \\
\hline QF & $0.4 \pm 0.1^{\mathrm{a}}$ & $0.9 \pm 0.2^{b}$ & $4.4 \pm 0.2^{\mathrm{c}}$ & $5.5 \pm 0.3^{d}$ & $2.6^{\mathrm{a}}$ \\
\hline TFAA (mg/Kg) & $214 \pm 10^{b}$ & $142 \pm 11^{a}$ & $338 \pm 12^{d}$ & $272 \pm 15^{\mathrm{c}}$ & $134 \pm 10^{a}$ \\
\hline Peptide concentration (mg/g) & $33.1 \pm 0.5^{b}$ & $30.2 \pm 0.4^{a}$ & $41.2 \pm 0.5^{d}$ & $38.4 \pm 0.4^{c}$ & $24.2 \pm 0.1$ \\
\hline \multicolumn{6}{|l|}{ Nutritional properties } \\
\hline Protein (\%) & $13.0 \pm 0.2^{b}$ & $13.1 \pm 0.4^{b}$ & $12.9 \pm 0.6^{b}$ & $13.1 \pm 0.3^{b}$ & $6.3 \pm 0.1^{a}$ \\
\hline Fat (\%) & $5.9 \pm 0.5^{b}$ & $6.5 \pm 0.3^{b}$ & $5.9 \pm 0.3^{b}$ & $6.5 \pm 0.5^{b}$ & $0.61 \pm 0.04^{a}$ \\
\hline Available carbohydrates (\%) & $70.2 \pm 1.7^{b}$ & $69.4 \pm 1.3^{b}$ & $69.4 \pm 1.3^{b}$ & $69.5 \pm 0.4^{b}$ & $76.5 \pm 0.9^{a}$ \\
\hline Total dietary fibers (\%) & $10.9 \pm 0.6^{b}$ & $10.8 \pm 0.5^{b}$ & $10.8 \pm 0.7^{b}$ & $10.8 \pm 0.3^{b}$ & $1.87 \pm 0.02^{a}$ \\
\hline IVPD (\%) & $48 \pm 3^{b}$ & $44 \pm 1^{b}$ & $72 \pm 1^{\mathrm{c}}$ & $70 \pm 2^{c}$ & $39 \pm 1^{a}$ \\
\hline$H I(\%)$ & $93 \pm 3^{c}$ & $87 \pm 1^{c}$ & $82 \pm 2^{b}$ & $77 \pm 1^{a}$ & $100 \pm 1$ \\
\hline Phytic acid (mg/100 g) & $340 \pm 4^{d}$ & $270 \pm 5^{c}$ & $70 \pm 4^{a}$ & $140 \pm 2^{b}$ & $234 \pm 6^{e}$ \\
\hline Total phenols (mmol/Kg) & $0.82 \pm 0.04^{a}$ & $0.99 \pm 0.03^{b}$ & $1.07 \pm 0.04^{c}$ & $1.20 \pm 0.02^{d}$ & $2.39 \pm 0.03^{\mathrm{e}}$ \\
\hline Radical scavenging (\%) on ME & $39.4 \pm 0.5^{b}$ & $53.1 \pm 0.4^{d}$ & $49.8 \pm 0.4^{c}$ & $58.0 \pm 0.4^{e}$ & $20.3 \pm 0.3^{a}$ \\
\hline Radical scavenging (\%) on WSE & $16.6 \pm 0.3^{a}$ & $22.4 \pm 0.5^{c}$ & $31.5 \pm 0.5^{d}$ & $33.7 \pm 0.4^{\mathrm{e}}$ & $18.2 \pm 0.3^{b}$ \\
\hline
\end{tabular}

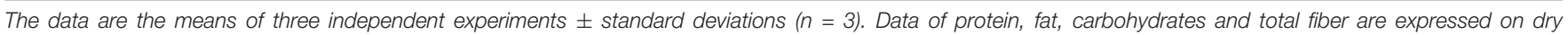

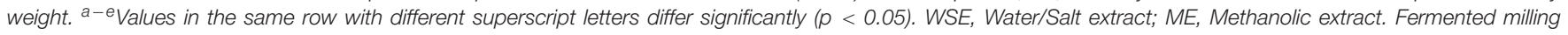

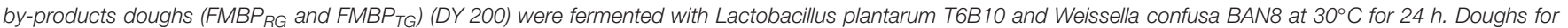
breadmaking had DY 180.

found when $\mathrm{FMBP}_{\mathrm{RG}}$ and $\mathrm{FMBP}_{\mathrm{TG}}$ were included in bread formula (Table 3). Nevertheless, higher values of phytic acids were found in $\mathrm{MBP}_{\mathrm{TG}}-\mathrm{B}$ and $\mathrm{MBP}_{\mathrm{RG}}-\mathrm{B}$ compared to $\mathrm{WB}$ (Table 3). The presence of milling by-products in bread led to higher concentration of total phenols than WB. Values 10$34 \%$ and $45-62 \%$ higher were found in $\mathrm{MBP}_{\mathrm{RG}}-\mathrm{B}$ and $\mathrm{MBP}_{\mathrm{TG}^{-}}$ $\mathrm{B}$ and $\mathrm{FMBP}_{\mathrm{RG}}-\mathrm{B}$ and $\mathrm{FMBP}_{\mathrm{TG}}-\mathrm{B}$, respectively, as compared WB. $\mathrm{MBP}_{\mathrm{TG}}-\mathrm{B}$ was characterized by higher concentration of total phenols as well as higher radical scavenging in both $\mathrm{ME}$ and WSE as compared to $\mathrm{MBP}_{\mathrm{RG}}-\mathrm{B}$. When $\mathrm{FMBP}_{\mathrm{TG}}$ and $\mathrm{FMBP}_{\mathrm{RG}}$ were used to fortify the bread, higher values of radical scavenging activities (ME and WSE) and total phenols concentration were found as compared to the corresponding un-fermented samples (Table 3).

\section{Structural Properties and Sensory Profile of the Breads}

After baking, structural and sensory analysis were carried out on $\mathrm{MBP}_{\mathrm{RG}}-\mathrm{B}, \mathrm{MBP}_{\mathrm{TG}}-\mathrm{B}, \mathrm{FMBP}_{\mathrm{RG}}-\mathrm{B}, \mathrm{FMBP}_{\mathrm{TG}}-\mathrm{B}$, and $\mathrm{WB}$. The specific volume of the breads was influenced by the addition of milling by-products and fermentation process indeed the inclusion of milling by-products caused a decrease of the specific volume up to $c a .6 \%\left(\mathrm{MBP}_{\mathrm{RG}}-\mathrm{B}, \mathrm{MBP}_{\mathrm{TG}}-\mathrm{B}\right)$ as compared to $\mathrm{WB}$. However, $\mathrm{FMBP}_{\mathrm{RG}}-\mathrm{B}, \mathrm{FMBP}_{\mathrm{TG}}-\mathrm{B}$ showed higher specific volume than the corresponding $\mathrm{MBP}_{\mathrm{RG}}-\mathrm{B}$ and $\mathrm{MBP}_{\mathrm{TG}}-\mathrm{B}$, respectively. Nevertheless, WB was characterized by the highest value. On the contrary, the hardness seemed to be influenced by both heat-treatment (increase) and fermentation (decrease) (Table 4). Compared to $\mathrm{WB}$, the inclusion of milling by-products led to an increase of the hardness, however, it was lower in fermented products compared to un-fermented. Moreover, the presence of RG led to an increase of the value as compared to TG.

Aiming at highlighting the effect of the fermentation on the sensory profile of fiber-rich breads, $\mathrm{MBP}_{\mathrm{RG}}-\mathrm{B}, \mathrm{MBP}_{\mathrm{TG}}-\mathrm{B}$, $\mathrm{FMBP}_{\mathrm{RG}}-\mathrm{B}$, and $\mathrm{FMBP}_{\mathrm{TG}}-\mathrm{B}$ were subjected to sensory analysis. The results are shown in Figure 2. PCA, representing $88 \%$ of the total variance of the data, showed that $\mathrm{FMBP}_{\mathrm{TG}}-\mathrm{B}$ and $\mathrm{FMBP}_{\mathrm{RG}}-\mathrm{B}$ were both scattered on the right zone of the plane because sharing the fermented, sourness, softness and bitterness aroma and taste. On the left part of the plane, the $\mathrm{MBP}_{\mathrm{TG}}-\mathrm{B}$, $\mathrm{MBP}_{\mathrm{RG}}-\mathrm{B}$ were distributed. The perception of rancidity, although with very low scores, was found in $\mathrm{MBP}_{\mathrm{RG}}-\mathrm{B}$ and $\mathrm{FMBP}_{\mathrm{RG}}-\mathrm{B}$. The analysis also pointed up perfect separation between breads containing RG and TG. Attributes such as toasted, nuts and nutty were perceived, as demonstrated by $\mathrm{PCA}$, only in $\mathrm{MBP}_{\mathrm{TG}}-\mathrm{B}$ and $\mathrm{FMBP}_{\mathrm{TG}}-\mathrm{B}$.

\section{DISCUSSION}

The growing interest of consumers in balanced nutrition, due to the increase in the number of overweight people in Western society, has refocused the food industry on the merits of 
TABLE 4 | Structural properties of breads: $\mathrm{MBP}_{\mathrm{RG}}-\mathrm{B}$, containing unfermented mixture of raw germ and bran (MBP $\mathrm{RG}_{\mathrm{R}}, 12.5 \%$, wt/wt); $\mathrm{MBP} \mathrm{TG}_{\mathrm{TG}}-\mathrm{B}$, containing unfermented mixture of heat-treated germ and bran $\left(\mathrm{MBP}_{\mathrm{TG}}, 12.5 \%\right.$, wt/wt); $\mathrm{FMBP}_{\mathrm{RG}}-\mathrm{B}$, containing fermented mixture of raw germ and bran (FMBP $\left.\mathrm{RG}, 25 \% \mathrm{wt} / \mathrm{wt}\right) ; \mathrm{FMBP} \mathrm{TG}_{\mathrm{T}}-\mathrm{B}$, containing fermented mixture of heat-treated germ and bran (FMBP $\left.{ }_{\mathrm{TG}}, 25 \% \mathrm{wt} / \mathrm{wt}\right)$; WB, wheat flour bread.

\begin{tabular}{|c|c|c|c|c|c|}
\hline & $\mathrm{MBP}_{\mathrm{RG}}-\mathrm{B}$ & MBP $_{\mathrm{TG}}-\mathrm{B}$ & FMBP $_{R G}-B$ & $\mathrm{FMBP}_{\mathrm{TG}}-\mathrm{B}$ & WB \\
\hline Specific volume $\left(\mathrm{cm}^{3} / \mathrm{g}\right)$ & $2.27 \pm 0.4^{c}$ & $2.29 \pm 0.3^{c}$ & $2.80 \pm 0.2^{b}$ & $2.70 \pm 0.2^{b}$ & $2.91 \pm 0.02^{\mathrm{a}}$ \\
\hline Resilience & $0.79 \pm 0.02^{a}$ & $0.89 \pm 0.04^{b}$ & $0.82 \pm 0.03^{a}$ & $0.86 \pm 0.03^{a, b}$ & $0.85 \pm 0.04^{\mathrm{a}, \mathrm{b}}$ \\
\hline Cohesiveness & $0.47 \pm 0.05^{a}$ & $0.48 \pm 0.02^{a}$ & $0.49 \pm 0.04^{a}$ & $0.49 \pm 0.02^{a}$ & $0.70 \pm 0.07^{b}$ \\
\hline Gumminess (N) & $24.5 \pm 0.6^{c}$ & $17.1 \pm 0.4^{b}$ & $38.2 \pm 0.7^{d}$ & $25.1 \pm 0.8^{c}$ & $7.3 \pm 0.2^{a}$ \\
\hline Chewiness (g) & $1930 \pm 21^{\mathrm{c}}$ & $1530 \pm 13^{b}$ & $3140 \pm 26^{e}$ & $2150 \pm 17^{d}$ & $825 \pm 13^{a}$ \\
\hline Hardness (g) & $7720 \pm 47^{d}$ & $5070 \pm 35^{c}$ & $5150 \pm 49^{c}$ & $3590 \pm 56^{b}$ & $2890 \pm 22^{a}$ \\
\hline \multicolumn{6}{|l|}{ Color crust } \\
\hline$L$ & $46.3 \pm 1.9^{b}$ & $42.3 \pm 1.2^{\mathrm{a}}$ & $47.3 \pm 2.7^{b}$ & $42.6 \pm 1.8^{a}$ & $68.1 \pm 0.7^{\mathrm{c}}$ \\
\hline a & $3.2 \pm 0.3^{b}$ & $5.01 \pm 1.2^{\mathrm{C}}$ & $3.6 \pm 0.4^{b}$ & $5.9 \pm 0.4^{\mathrm{c}}$ & $2.5 \pm 0.1^{a}$ \\
\hline$b$ & $17.4 \pm 0.6^{a}$ & $17.3 \pm 0.4^{a}$ & $18.7 \pm 0.7^{b}$ & $18.2 \pm 0.5^{a, b}$ & $23.4 \pm 0.3^{b}$ \\
\hline$\Delta E$ & $48.5 \pm 1.2^{b}$ & $52.8 \pm 0.7^{c}$ & $47.9 \pm 0.6^{b}$ & $52.8 \pm 0.6^{c}$ & $33.1 \pm 0.5^{a}$ \\
\hline
\end{tabular}

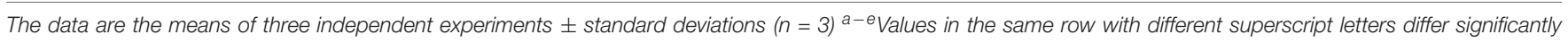

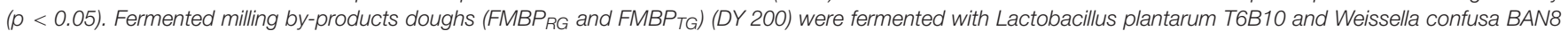
at $30^{\circ} \mathrm{C}$ for $24 \mathrm{~h}$. Doughs for breadmaking had DY 180.

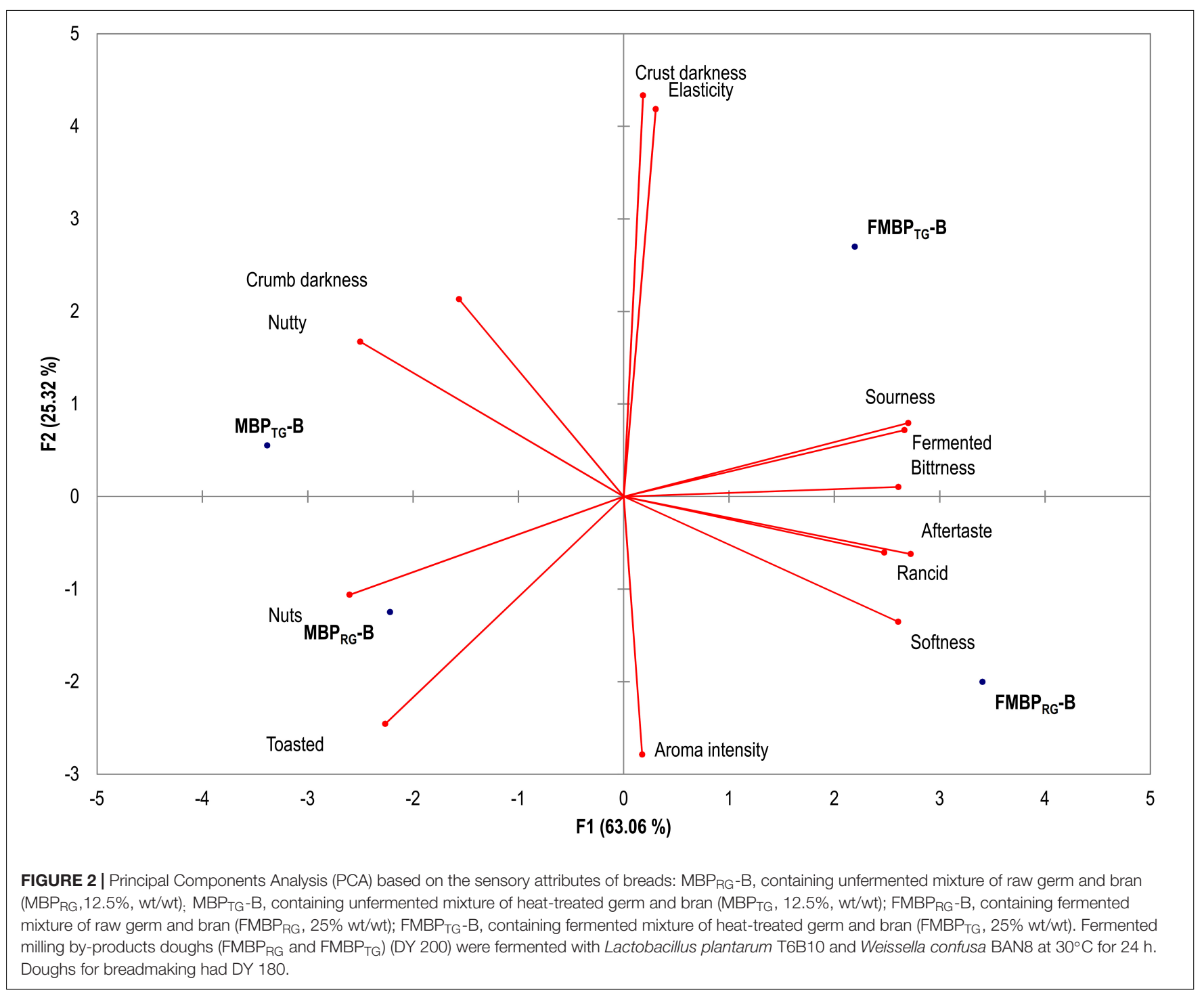


including some form of dietary fiber in food products (Redgwell and Fischer, 2005). Besides the well-known functional effects related to the nutrient absorption modification and the prebiotic capability, the importance of the dietary fiber is increasing due to its beneficial effects on the reduction of cholesterol levels and the risk of colon cancer (Lattimer and Haub, 2010). Health authorities, world-wide, recommend an increase of cereal derived foods in diet, since recognized as potential source of dietary fiber, especially when employed as whole grains (Dahl et al., 2015). The widespread consumption of cereals all over the world and the tradition of breadmaking give bread an important position in international nutrition being a popular staple food for ages. Nevertheless, white bread, obtained by refined flour, is the most consumed type of bread. Therefore, aiming at meeting the recommendations regarding the dietary fiber intake, the development of high fiber bread could be a promising strategy. Producing fortified/enriched products without compromising their sensory appeal, seems to be a real challenge for the food industry. Indeed, the consumer wants variety, good taste but no constraints and sometime placed nutrition second in importance to taste in factors for food selection (Sandvik et al., 2018). Among ingredients, milling by-products (bran and germ) are considered suitable fiber sources to be used as bread ingredients (Hemdane et al., 2016). Nevertheless, the increase in fiber content causes several issues, such as the decrease of loaf volume and softness, and the decrease in consumer acceptability (Wang et al., 2002). Moreover, in the case of germ, a stabilization prior the inclusion in flour is strictly required to avoid oxidative rancidity (Leenhardt et al., 2006), due to the concomitant presence of lipids and lipases (Tovey and Hobsley, 2004). Maize and its milling by-products are often contaminated with mycotoxins produced by fungi of the genera Aspergillus, Fusarium, and Penicillium (Fountain et al., 2014; Munkvold et al., 2019). Management of mycotoxin problems requires a multifaceted approach including preharvest and postharvest strategies (Okeke et al., 2015; Burns et al., 2018) for preventing mycotoxin accumulation, and a strict control of the matrix intended for food and feed uses (Munkvold et al., 2019). From the nutritional point of view, besides the positive contribution of tocopherols, fiber, high quality protein, iron, zinc and vitamins (Naves et al., 2009), the abundance of anti-nutritional factors (e.g., phytic acid) characterizing milling by-products may lower the overall quality of fortified breads (Rizzello et al., 2012; Hemdane et al., 2016).

The application of the sourdough-type fermentation, involving LAB as natural or selected starters, has largely been proposed as valuable biotechnology able to solve the above mentioned technological, stabilization and nutritional problems related to the employment of cereal milling by-products as bread ingredient (Arte et al., 2015; Pontonio et al., 2017), allowing the exploitation of by-products generally treated as wastes. The production of value-added products from food processing wastes have gained worldwide attention (Wang and Chen, 2010; Burns et al., 2018) due to the economical but also environmental implications (Galanakis, 2012).

Among cereals, maize (Pranjal et al., 2017) is grown throughout the world and although the good nutritional profile its use as food ingredient is second to the fuel production (Ranum et al., 2014). Similarly, to wheat, maize milling methods produce a variety of economically and nutritionally valuable co-products, which can be used as food ingredient (Naves et al., 2009).

This study aimed at improving the nutritional profile of wheat bread using raw- and heat-treated wastes of maize milling process fermented by selected LAB.

Apart from the moisture, RG and TG had similar proximate composition. As expected, cell density of the different microbial groups considered was in TG very low, as the consequence of the thermal process, while in RG and B samples microbial contaminations were observed, at different level. However, Enterobacteriaceae were not found ( $<10 \mathrm{cfu} / 1 \mathrm{~g})$ showing the good hygienic status of all the samples (Cordier, 2006) meeting food quality and safety standards. Either RG or TG were combined, with $B$ in a ratio of $2: 1$ according to their presence in the maize kernel (ca. 11 and 5\%, respectively) (Gwirtz and Garcia-Casal, 2013), before use and characterization. Doughs were prepared $\left(\mathrm{MBP}_{\mathrm{RG}}\right.$ and $\left.\mathrm{MBP}_{\mathrm{TG}}\right)$ mixing milling byproducts and water in a ratio of $1: 1$ and fermented $\left(\mathrm{FMBP}_{\mathrm{RG}}\right.$ and $\mathrm{FMBP}_{\mathrm{TG}}$ ) with two LAB strains, L. plantarum T6B10 and $W$. confusa BAN8, previously selected according to their protechnological, biochemical and nutritional features (kinetics of growth and acidification, proteolytic, phytase and antioxidant activity) (Pontonio et al., 2015; Rizzello et al., 2016). Overall, $\mathrm{MBP}_{\mathrm{TG}}$ was characterized by lower concentration of lactic acid, TFFA, peptide and phytic acid as compared to $\mathrm{MBP}_{\mathrm{RG}}$. The partial denaturation of the endogenous proteases and the significant decrease of the resident microbiota due to the heat-treatment might explain the lower values of TFFA and peptides concentrations. Similarly, the dejection of LAB, and more in general, microbial density led to a reduction of lactic acid in the TG.

Lactic acid bacteria fermentation led, as expected, to a relevant decrease of the $\mathrm{pH}$ due to the synthesis of lactic and acetic acids (Gobbetti et al., 2005). Moreover, FMBP RG $_{\text {and }}$ FMBP $_{\mathrm{TG}}$ were characterized by higher concentration of TFAA compared to $\mathrm{MBP}_{\mathrm{RG}}$ and $\mathrm{MBP}_{\mathrm{TG}}$. Sourdough fermentation resulted in an increase of amino acid concentrations due to the proteolytic activity of sourdough LAB and endogenous proteases which have been activated under the acidic conditions of sourdough fermentation (Thiele et al., 2002). TFAA and peptides concentrations were higher in $\mathrm{FMBP}_{\mathrm{RG}}$ than in $\mathrm{FMBP}_{\mathrm{TG}}$, thus hypothesizing a contribution of the activity of endogenous proteases of the raw germ to the microbial proteolysis. The lower lactic acid concentration detected in $\mathrm{FMBP}_{\mathrm{RG}}$ may be explained by the reduced acidification efficiency of the inoculated LAB, affected by the competition of the endogenous microbiota.

The digestibility of protein, bioavailability of amino acids and protein quality of foods can be weakened by the presence of dietary anti-nutritional factors (Soetan and Oyewole, 2009). Phytic acid is an anti-nutritional factor because works as an excellent chelator of minerals, complexes the basic amino acid group of proteins, thus decreasing their dietary bioavailability (Febles et al., 2002). Fermentation with LAB contributed to create the optimal environment for phytase (myo-inositol-hexakisphosphate phosphohydrolase, EC 3.1.3.8) 
(Poutanen et al., 2009) which decreased the concentration of

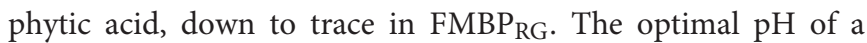
purified phytase from maize seedlings was 4.8 (Laboure et al., 1993). The proteolysis operated by endogenous proteases and microbial peptidase during the fermentation may have led to the release of peptides with antioxidant activity, thus explaining the increase of the radical scavenging activity in the WSE in FMBP $_{\text {RG }}$ and $\mathrm{FMBP}_{\mathrm{TG}}$. Although the LAB fermentation often leads to an increase of the solubilization of phenolic compounds having antioxidant activity, due to the biological acidification and the microbial enzymatic activity (e.g., feruloyl-esterase and $\beta$-glucosidase activities) radical scavenging activity as well as in the $\mathrm{ME}$ and total phenols concentration $\mathrm{FMBP}_{\mathrm{RG}}$ and $\mathrm{FMBP}_{\mathrm{TG}}$ were not significantly different than $\mathrm{MBP}_{\mathrm{RG}}$ and $\mathrm{MBP}_{\mathrm{TG}}$.

Data of the biochemical and nutritional characterization of $\mathrm{MBP}_{\mathrm{RG}}, \mathrm{MBP}_{\mathrm{TG}}, \mathrm{FMBP}_{\mathrm{RG}}$, and $\mathrm{FMBP}_{\mathrm{TG}}$ were subjected to Principal Components Analysis (PCA) (Figure 3). The factors explained the $98.7 \%$ of the total variance and clearly differentiated the $\mathrm{MBP}_{\mathrm{RG}}$ and $\mathrm{MBP}_{\mathrm{TG}}$ form the corresponding fermented $\mathrm{FMBP}_{\mathrm{RG}}$ and $\mathrm{FMBP}_{\mathrm{TG}}$. Indeed, the former and the latter are scattered on the left and right part of the plane, respectively. Overall, $\mathrm{FMBP}_{\mathrm{RG}}$ and $\mathrm{FMBP}_{\mathrm{TG}}$ seem to be characterized by a more complex profile than the corresponding $\mathrm{MBP}_{\mathrm{TG}}$ and
$\mathrm{MBP}_{\mathrm{RG}}$, with improved nutritional features. According to the literature, maize germ contains lipases which are responsible for the fatty acid oxidation leading to unstable product with poor quality (Paradiso et al., 2008; Rizzello et al., 2010). Under this study conditions, the lactic acid fermentation was proposed as valuable alternative to heat treatment aiming at decreasing the lipase activity of maize germ. Indeed, $\mathrm{MBP}_{\mathrm{RG}}$ was the only sample showing activity, however, a strong inhibition was achieved through the fermentation $\left(\mathrm{FMBP}_{\mathrm{RG}}\right)$. As expected, similar results were observed when the heat treatment $\left(\mathrm{MBP}_{\mathrm{TG}}\right.$ and $\left.\mathrm{FMBP}_{\mathrm{TG}}\right)$ was used; however, it may have decrease of the nutritional value of maize germ (Paradiso et al., 2008; Rizzello et al., 2010).

$\mathrm{FMBP}_{\mathrm{RG}}$ and $\mathrm{FMBP}_{\mathrm{TG}}$ were used as ingredient for the manufacture of wheat bread, whose characteristics were compared to those of breads manufactured with $\mathrm{MBP}_{\mathrm{RG}}$ and $\mathrm{MBP}_{\mathrm{TG}}$. Overall, the nutritional properties of white bread have been improved through the inclusion of milling by-products in the formula. However, the best improvements were observed when $\mathrm{FMBP}_{\mathrm{RG}}$ and $\mathrm{FMBP}_{\mathrm{TG}}$ were used. Indeed, according to the high content of organic acids in fermented samples, FMBP $\mathrm{RG}^{-B}$ and $\mathrm{FMBP}_{\mathrm{TG}}-\mathrm{B}$ were characterized by optimal $\mathrm{QF}$ for sensory profile (Minervini et al., 2012) and acetic acid concentration, associated to the extended microbiological shelf-life

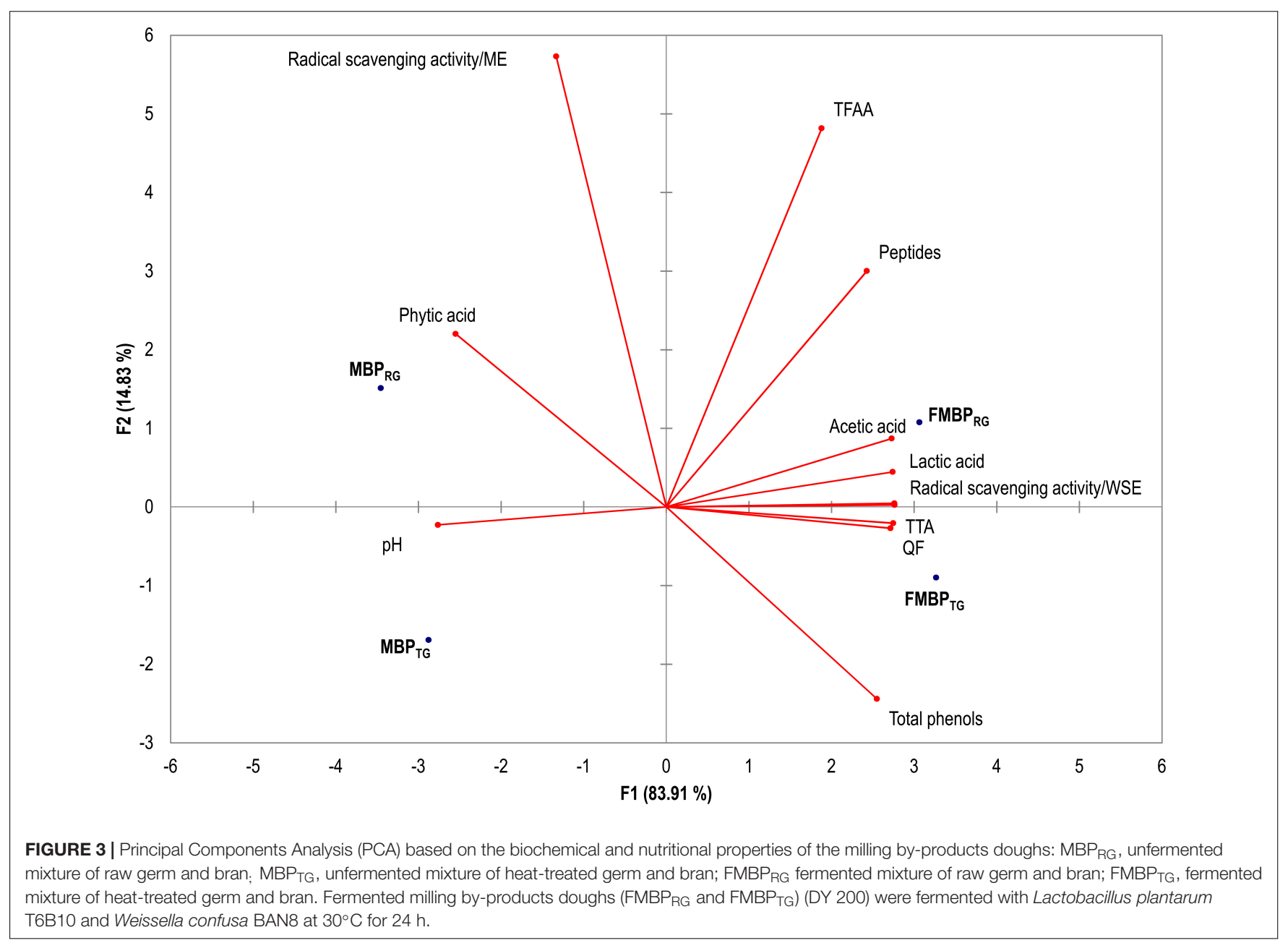


(Katina, 2005). Improvements in TFAA and peptides concentrations, as well as the phytic acid degradation and the enhancement of the radical scavenging activity (WSE) in bread containing fermented milling by-products, were also found. According to the literature, when dietary fiber is used in breadmaking, the loaf volume and shelf-life are often compromised. Bran is the main responsible for the weak structure and poor baking quality (low bread volume and elasticity of crumb) in fiber enriched bread (Katina, 2005). These effects on the dough structure are due to the dilution of the gluten network, which in turn impairs gas retention rather than gas production. Thus, the supplementation of dietary fiber requires changes in processing techniques to produce baked goods with good consumer quality. The sourdough was proposed as strategy to overcome the downsides in breadmaking due to the high fiber contents (Katina, 2005; Pontonio et al., 2017). Under these study conditions, the specific volume and the hardness of $\mathrm{FMBP}_{\mathrm{TG}}-\mathrm{B}$ and $\mathrm{FMBP}_{\mathrm{RG}}-\mathrm{B}$ were higher and lower, respectively, than the corresponding $\mathrm{MBP}_{\mathrm{TG}}-\mathrm{B}$ and $\mathrm{MBP}_{\mathrm{RG}}-\mathrm{B}$ corroborating the previous findings (Katina, 2005; Katina et al., 2006b; Rizzello et al., 2012).

High fiber content (Regulation EC No. 1924/2006, 2006) was achieved including milling by-products in bread, however, the fermentation with LAB positively affected other nutritional features, i.e., IVPD and HI, leading to a bread with high nutritional profile. High protein content and digestibility was achieved when fermented milling by-products were used to fortify wheat bread. A high content of protein (ca. 13\% of d.m.) as well as values of IVPD up to $c a$. $60 \%$ were observed. The latter were mainly due to the intense proteolysis operated by endogenous and microbial enzymes (Pontonio et al., 2017). The predicted GI was also investigated, through the study of the starch hydrolysis kinetic in vitro conditions. Due to the biological acidification, lactic acid bacteria fermentation can be used to decrease the starch hydrolysis during digestion (De Angelis et al., 2009). Indeed, $\mathrm{FMBP}_{\mathrm{RG}}-\mathrm{B}$ and $\mathrm{FMBP}_{\mathrm{TG}}-\mathrm{B}$ showed lower values as compared to the corresponding $\left(\mathrm{MBP}_{\mathrm{RG}}-\mathrm{B}\right.$ and $\left.\mathrm{MBP}_{\mathrm{TG}}-\mathrm{B}\right)$.

The sensory acceptability of the breads was assessed by a panel test, and although all breads were appreciated, those containing fermented milling by-products showed a more balanced profile. Moreover, breads fortified with $\mathrm{FMBP}_{\mathrm{RG}}$ and $\mathrm{FMBP}_{\mathrm{TG}}$ were characterized by acidic aroma and taste typical of sourdough breads (Katina et al., 2006a).

The results of this study demonstrate that fermentation with $\mathrm{LAB}$ led the improvement of nutritional properties of maize milling by-products through the increase of free amino acids, peptides concentrations and antioxidant activity, and the

\section{REFERENCES}

Akeson, W. R., and Stahmann, M. A. (1964). A pepsin pancreatin digest index of protein quality evaluation. J. Nutr. 83, 257-261. doi: 10.1093/jn/83. 3.257

American Association of Cereal Chemists [AACC] (2010). International Approved Methods of Analysis. St Paul: AACC International.

Arte, E., Rizzello, C. G., Verni, M., Nordlund, E., Katina, K., and Coda, R. (2015). Impact of Enzymatic and microbial bioprocessing on protein modification decrease of the antinutritional phytic acid. Fermentation also caused the chemical stabilization of the by-products through the inhibition of the lipase activity, thus suggesting an alternative use to heat-treatment which often impair the nutritional profile of germ.

\section{CONCLUSION}

This study demonstrates the potential of fermentation to convert maize bran and germ, commonly considered food wastes, into nutritive improvers, meeting nutritional and sensory requests of modern consumer. The fortification of wheat bread with maize milling by-products allows the increase in dietary fiber and proteins compared to a conventional wheat bread. When fermented, milling by-products also conferred to fortified bread the advantages commonly related to the sourdough fermentation, such as the increase of the protein digestibility, the decrease of the starch hydrolysis, the degradation of phytic acid. Moreover, LAB fermentation as pre-processing treatment positively affects the textural properties and the sensory profile of the breads.

\section{AUTHOR CONTRIBUTIONS}

EP conceived the study, elaborated the results, and wrote the draft of the manuscript. CD carried out the experiments. MG was the scientific advisor and responsible for financial contribution. CR supervised the work and critically revised the manuscript. All authors read and approved the final manuscript.

\section{ACKNOWLEDGMENTS}

We are grateful to Loredana Favero and Alessia Giannoni of Molino Favero (Padova, Italy) and thank them for providing heat treated- and raw maize (Zea mays) germ and bran. We would also like to thank Vito Paradiso and Maria Castellino (Department of Soil, Plant and Food Science, University of Bari, Italy) for performing the structural analysis of the breads.

\section{SUPPLEMENTARY MATERIAL}

The Supplementary Material for this article can be found online at: https://www.frontiersin.org/articles/10.3389/fmicb. 2019.00561/full\#supplementary-material

and nutritional properties of wheat bran. J. Agr. Food Chem. 63, 8685-8693. doi: 10.1021/acs.jafc.5b03495

Bradford, M. M. (1976). A rapid and sensitive method for the quantitation of microgram quantities of protein utilizing the principle of protein-dye binding. Anal. Biochem. 72, 248-254. doi: 10.1016/0003-2697(76)90527-3

Burns, P., Borgo, M. F., Binetti, A., Puntillo, M., Bergamini, C., Páez, R., et al. (2018). Isolation, characterization and performance of autochthonous spray dried lactic acid bacteria in maize micro and bucket-silos. Front. Microbiol. 9:2861. doi: 10.3389/fmicb.2018.02861 
Capriles, V. D., and Areas, J. A. G. (2013). Effects of prebiotic inulin-type fructans on structure, quality, sensory acceptance and glycemic response of gluten-free breads. Food Funct. 4, 04-10. doi: 10.1039/c2fo10283h

Church, F. C., Swaisgood, H. E., Porter, D. H., and Catignani, G. L. (1983). Spectrophotometric assay using o-phthaldialdehyde for determination of proteolysis in milk and isolated milk proteins. J. Dairy Sci. 66, 1219-1227. doi: 10.3168/jds.S0022-0302(83)81926-2

Cordier, J. L. (2006). "Enterobacteriaceae," in Emerging Foodborne Pathogens, eds Y. Motarjemi and M. Adams (Cambridge: Woodhead Publishing Limited), 450-475. doi: 10.1533/9781845691394.2.450

Dahl, W. J., Gainesville, F. L., Stewart, M. L., and Honolulu, H. I. (2015). Position of the academy of nutrition and dietetics: health implications of dietary fiber. J. Acad. Nutr. Diet. 115, 1861-1870. doi: 10.1016/j.jand.2015.09.003

De Angelis, M., Damiano, N., Rizzello, C. G., Cassone, A., Di Cagno, R., and Gobbetti, M. (2009). Sourdough fermentation as a tool for the manufacture of low-glycemic index white wheat bread enriched in dietary fibre. Eur. Food Res. Technol. 229, 593-601. doi: 10.1007/s00217-009-1085-1

Febles, C. I., Arias, A., Hardisson, A., Rodrı̀̀guez-Alvarez, C., and Sierra, A. (2002). Phytic acid level in wheat flours. J. Cereal Sci. 36, 19-23. doi: 10.1006/jcrs.2001. 0441

Fernstrand, A. M., Bury, D., Garssen, J., and Verster, J. C. (2017). Dietary intake of fibers: differential effects in men and women on perceived general health and immune functioning. Food Nutr. Res. 61:1297053. doi: 10.1080/16546628.2017. 1297053

Fountain, J., Scully, B., Ni, X., Kemerait, R., Lee, D., Zhi-Yuan, C., et al. (2014). Environmental influences on maize-Aspergillus flavus interactions and aflatoxin production. Front. Microbiol. 5:40. doi: 10.3389/fmicb.2014.00040

Frauenlob, J., Scharl, M., D'Amico, S., and Schoenlechner, R. (2018). Effect of different lipases on bread staling in comparison with Diacetyl tartaric ester of monoglycerides (DATEM). Cereal Chem. 95, 367-372. doi: 10.1002/cche. 10047

Galanakis, C. M. (2012). Recovery of high added-value components from food wastes: conventional, emerging technologies and commercialized applications. LWT Food Sci. Tech. 26, 68-87. doi: 10.1016/j.tifs.2012.03.003

Georgsson, F. (2015). Guidelines for sensory evaluation of bread. NMKL Proced. $31,1-25$.

Gobbetti, M., De Angelis, M., Corsetti, A., and Di Cagno, R. (2005). Biochemistry and physiology of sourdough lactic acid bacteria. Trends Food Sci. Technol. 16, 57-69. doi: 10.1016/j.tifs.2004.02.013

Gwirtz, J. A., and Garcia-Casal, M. N. (2013). Processing maize flour and corn meal food products. Ann. N.Y. Acad. Sci. 1312:75. doi: 10.1111/nyas.12299

Haglund, A., Johansson, L., and Dahlstedt, L. (1998). Sensory evaluation of wholemeal bread from ecologically and conventionally grown wheat. J. Cereal Sci. 27, 199-207. doi: 10.1006/jcrs.1997.0155

Hemdane, S., Jacobs, P. J., Dornez, E., Verspreet, J., Delcour, J. A., and Courtin, C. M. (2016). Wheat (Triticum aestivum L.) bran in bread making. Compr. Rev. Food Sci. Food Safety 15, 28-42. doi: 10.1111/1541-4337.12176

Howarth, N. C., Saltzman, E., and Roberts, S. B. (2001). Dietary fiber and weight regulation. Nutr. Rev. 59, 129-139. doi: 10.1111/j.1753-4887.2001.tb07001.x

Kaczmarczyk, M. M., Miller, M. J., and Freund, G. G. (2012). The health benefits of dietary fiber: beyond the usual suspects of type 2 diabetes mellitus, cardiovascular disease and colon cancer. Metab. Clin. Exp. 61, 1058-1066. doi: 10.1016/j.metabol.2012.01.017

Katina, K. (2005). Sourdough: a Tool for the Improved Flavour, Texture and ShelfLife of Wheat Bread. Doctoral dissertation, University of Helsinki, Helsinki.

Katina, K., Juvonen, R., Laitila, A., Flander, L., Nordlund, E., Kariluoto, S., et al. (2012). Fermented wheat bran as a functional ingredient in baking. Cereal Chem. 89, 126-134. doi: 10.1094/CCHEM-08-11-0106

Katina, K., Heinio, R. L., Autio, K., and Poutanen, K. (2006a). Optimization of sourdough process for improved sensory profile and texture of wheat bread. LWT Food Sci. Tech. 39, 1189-1202. doi: 10.1016/j.lwt.2005.08.001

Katina, K., Salmenkallio-Marttila, M., Partanen, R., Forssell, P., and Autio, K. (2006b). Effects of sourdough and enzymes on staling of high-fibre wheat bread. LWT Food Sci. Tech. 39, 479-491. doi: 10.1016/j.lwt.2005.03.013

Laboure, A. M., Gagnon, J., and Lescure, A. M. (1993). Purification and characterization of a phytase (myo-inositol-hexakisphosphate phosphohydrolase) accumulated in maize (Zea mays) seedlings during germination. Biochem. J. 295, 413-419. doi: 10.1042/bj2950413
Lattimer, J. M., and Haub, M. D. (2010). Effects of dietary fiber and its components on metabolic health. Nutrients 2, 1266-1289. doi: 10.3390/nu2121266

Lawrence, R. C., Fryer, T. F., and Reiter, B. (1967). Rapid method for the quantitative estimation of microbial lipases. Nature 213, 1264-1265. doi: 10. 1038/2131264a0

Leenhardt, F., Lyan, B., Rock, E., Boussard, A., Potus, J., Chanliaud, E., et al. (2006). Genetic variability of carotenoid concentration, and lipoxygenase and peroxidase activities among cultivated wheat species and bread wheat varieties. Eur. J. Agron. 25, 170-176. doi: 10.1016/j.eja.2006.04.010

Lin, Y. H., Wimer, L. T., and Huang, A. H. (1983). Lipase in the lipid bodies of corn scutella during seedling growth. Plant Pathol. 73, 460-463. doi: 10.1104/pp.73. 2.460

Lopez, H. W., Adam, A., Leenhardt, F., Scalbert, A., and Remesy, C. (2001). Control of the nutritional value of bread. Industries des Ce. 124, 15-20.

Mamhoud, A., Nionelli, L., Bouzaine, T., Hamdi, M., Gobbetti, M., and Rizzello, C. G. (2016). Selection of lactic acid bacteria isolated from tunisian cereals and exploitation of the use as starters for sourdough fermentation. Int. J. Food Microbiol. 225, 9-19. doi: 10.1016/j.ijfoodmicro.2016.03.004

Minervini, F., Di Cagno, R., Lattanzi, A., De Angelis, M., Antonielli, L., Cardinali, G., et al. (2012). Lactic acid bacterium and yeast microbiotas of 19 sourdoughs used for traditional/typical Italian breads: interactions between ingredients and microbial species diversity. Appl. Environ. Microbiol. 78, 1251-1264. doi: 10.1128/AEM.07721-11

Munkvold, G. P., Arias, S., Taschl, I., and Gruber-Dorninger, C. (2019). "Mycotoxins in corn: occurrence, impacts, and management," in Corn Chemistry and Technology, ed. S. O. Serna-Saldivar (Cambridge: Woodhead Publishing), 235-287. doi: 10.1016/B978-0-12-811971-6.00009-7

Naves, M. M., De Castro, M. V. L., De Mendonça, A. L., Santos, G. G., and Silva, M. S. (2009). Corn germ with pericarp in relation to whole corn: nutrient contents, food and protein efficiency, and protein digestibilitycorrected amino acid score. Ciênc. Tecnol. Aliment. 31, 264-269. doi: 10.1590/ S0101-20612011000100040

Nionelli, L., Currib, N., Curiel, J. A., Di Cagno, R., Pontonio, E., Cavoski, I., et al. (2014). Exploitation of Albanian wheat cultivars: characterization of the flours and lactic acid bacteria microbiota, and selection of starters for sourdough fermentation. Food Microbiol. 44, 96-107. doi: 10.1016/j.fm.2014. 05.011

Nionelli, L., Montemurro, M., Pontonio, E., Verni, M., Gobbetti, M., and Rizzello, C. G. (2018a). Pro-technological and functional characterization of lactic acid bacteria to be used as starters for hemp (Cannabis sativa L.) sourdough fermentation and wheat bread fortification. Int. J. Food Microbiol. 279, 14-25. doi: 10.1016/j.ijfoodmicro.2018.04.036

Nionelli, L., Pontonio, E., Gobbetti, M., and Rizzello, C. G. (2018b). Use of hop extract as antifungal ingredient for bread making and selection of autochthonous resistant starters for sourdough fermentation. Int. J. Food Microbiol. 266, 173-182. doi: 10.1016/j.ijfoodmicro.2017.12.002

Noort, M. W. J., Van Haaster, D., Hemery, Y., Schols, H. A., and Hamer, R. J. (2010). The effect of particle size of wheat bran fractions on bread quality - evidence for fibre - protein interactions. J. Cereal Sci. 52, 59-64. doi: 10.1016/j.jcs.2010. 03.003

Okeke, C. A., Ezekiel, C. N., Nwangburuka, C. C., Sulyok, M., Ezeamagu, C. O., Adeleke, R. A., et al. (2015). Bacterial diversity and mycotoxin reduction during maize fermentation (steeping) for Ogi production. Front. Microbiol. 6:1402. doi: $10.3389 /$ fmicb.2015.01402

Osborne, T. B. (1907). Proteins of the Wheat Kernel. Washington, DC: Carnegie Institution, 1-119. doi: 10.5962/bhl.title.26152

Paradiso, V. M., Summo, C., Trani, A., and Caponio, F. (2008). An effort to improve the shelf life of breakfast cereals using natural mixed tocopherols. J. Cereal Sci. 47, 322-330. doi: 10.1016/j.jcs.2007.04.009

Pontonio, E., Lorusso, A., Gobbetti, M., and Rizzello, C. G. (2017). Use of fermented milling by-products as functional ingredient to develop a lowglycaemic index bread. J. Cereal Sci. 77, 235-242. doi: 10.1016/j.jcs.2017. 08.022

Pontonio, E., Nionelli, L., Curiel, J. A., Sadeghi, A., Di Cagno, R., Gobbetti, M., et al. (2015). Iranian wheat flours from rural and industrial mills: exploitation of the chemical and technology features, and selection of autochthonous sourdough starters for making breads. Food Microbiol. 47, 99-110. doi: 10.1016/j.fm.2014. 10.011 
Poutanen, K., Flander, L., and Katina, K. (2009). Sourdough and cereal fermentation in a nutritional perspective. Food Microbiol. 26, 693-699. doi: 10.1016/j.fm.2009.07.011

Pranjal, Y., Alok, A., Reeva, S., Ishwar, S., Tanushri, K., Arunava, P., et al. (2017). Advances in maize transformation technologies and development of transgenic maize. Front. Plant Sci. 7:1949. doi: 10.3389/fpls.2016.01949

Preedy, V. R., Watson, R. R., and Patel, V. B. (2011). Flour and Breads and their Fortification in Health and Disease Prevention. London: Academic Press.

Ranum, P., Peña-Rosas, J. P., and Garcia-Casal, M. N. (2014). Global maize production, utilization, and consumption. Ann. N. Y. Acad. Sci. 1312, 105-112. doi: $10.1111 /$ nyas. 12396

Redgwell, R. J., and Fischer, M. (2005). Dietary fiber as a versatile food component: an industrial perspective. Mol. Nutr. Food. Res. 49, 421-535. doi: 10.1002/mnfr. 200500028

Regulation EC No. 1924/2006 (2006). Regulation EC No. 1924/2006 the European. (Parliament) and of the Council of 20 December 2006 on Nutrition and Health Claims Made on Foods. Available at: https://eur-lex.europa.eu/eli/reg/2006/ 1924/2012-11-29

Rizzello, C. G., Coda, R., Mazzacane, F., Minervini, D., and Gobbetti, M. (2012). Micronized by-products from debranned durum wheat and sourdough fermentation enhanced the nutritional, textural and sensory features of bread. Food Res. Int. 46, 304-313. doi: 10.1016/j.foodres.2011.12.024

Rizzello, C. G., Curiel, J., Nionelli, L., Vincentini, O., Di Cagno, R., Silano, M., et al. (2014). Use of fungal proteases and selected sourdough lactic acid bacteria for making wheat bread with an intermediate content of gluten. Food Microbiol. 37, 59-68. doi: 10.1016/j.fm.2013.06.017

Rizzello, C. G., Lorusso, A., Montemurro, M., and Gobbetti, M. (2016). Use of sourdough made with quinoa (Chenopodium quinoa) four and autochthonous selected lactic acid bacteria for enhancing the nutritional, textural and sensory features of white bread. Food Microbiol. 56, 1-13. doi: 10.1016/j.fm.2015.11. $018 \mathrm{O}$

Rizzello, C. G., Nionelli, L., Coda, R., De Angelis, M., and Gobbetti, M. (2010). Effect of sourdough fermentation on stabilization, and chemical and nutritional characteristics of wheat germ. Food Chem. 119, 1079-1089. doi: 10.1016/j. foodchem.2009.08.016

Rosell, C. M., Bajerska, J., and El Sheikha, A. F. (2016). Bread and Its Fortification Bread Nutrition and Health Benefits. Didcot: Tyalor, and Francis Group.

Sandvik, P., Nydahl, M., Kihlberg, I., and Marklinder, I. (2018). Consumers' health-related perceptions of bread - implications for labeling and health communication. Appetite 121, 285-293. doi: 10.1016/j.appet.2017.11.092

Singh, K. P., Mishra, A., and Mishra, H. N. (2012). Fuzzy analysis of sensory attributes of bread prepared from millet-based composite flours. LWT Food Sci. Tech. 48, 276-282. doi: 10.1016/j.lwt.2012.03.026

Sivam, A. S., Sun-Waterhouse, D., Quek, S., and Conrad, O. (2010). Properties of bread dough with added fiber polysaccharides and phenolic antioxidants: a review. J. Food Sci. 75:8. doi: 10.1111/j.1750-3841.2010.01815.x
Sjovall, O., Virtalaine, T., Lapvetelainen, A., and Kallio, H. (2000). Development of rancidity in wheat germ analyzed by headspace gas chromatography and sensory analysis. J. Agric. Food Chem. 48, 3522-3527. doi: 10.1021/jf981309t

Slinkard, K., and Singleton, V. (1977). Total phenol analysis: automation and comparison with manual methods. Am. J. Enol. Viticult. 28, 49-55. doi: 10.3390/ molecules 15128618

Soetan, K. O., and Oyewole, O. E. (2009). The need for adequate processing to reduce the anti-nutritional factors in plants used as human foods and animal feeds. Afr. J. Food Sci. 3, 223-232.

Stephen, A. M., Champ, M. M.-J., Cloran, S. J., Fleith, M., Van Lieshout, L., Mejborn, H., et al. (2017). Dietary fibre in Europe: current state of knowledge on definitions, sources, recommendations, intakes and relationships to health. Nutr. Res. Rev. 1:42. doi: 10.1017/S09544224170 $0004 \mathrm{X}$

Thiele, C., Gänzle, M. G., and Vogel, R. F. (2002). Contribution of sourdough lactobacilli, yeast, and cereal enzymes to the generation of amino acids in dough relevant for bread flavor. Cereal Chem. 79, 45-45. doi: 10.1094/CCHEM.2002. 79.1 .45

Tovey, F. I., and Hobsley, M. (2004). Milling of wheat, maize and rice: effects on fibre and lipid content and health. World J. Gastroenterol. 10, 1695-1696. doi: 10.3748/wjg.v10.i12.1695

Wang, J., Rosell, C. M., and De Barber, C. B. (2002). Effect of the addition of different fibres on wheat dough performance and bread quality. Food Chem. 79, 221-226. doi: 10.1016/S0308-8146(02)00135-8

Wang, S. Y., and Chen, C. T. (2010). Effect of allyl isothiocyanate on antioxidant enzyme activities, flavonoids and post-harvest fruit quality of blueberries (Vaccinium corymbosum L., cv. Duke). Food Chem. 122, 1153-1158. doi: 10. 1016/j.foodchem.2010.03.106

Weiss, W., Vogelmeier, C., and Gorg, A. (1993). Electrophoretic characterization of wheat grain allergens from different cultivars involved in bakers' asthma. Electrophoresis 14, 805-816. doi: 10.1002/elps.11501401126

WHO, (2018). Obesity and Overweight. Available at: https://www.who.int/newsroom/fact-sheets/detail/obesity-and-overweight

Zwietering, M. H., Jongeberger, I., Roumbouts, F. M., and Van't Riet, K. (1990). Modelling of bacterial growth curve. Appl. Environ. Microbiol. 56, 1875-1881.

Conflict of Interest Statement: The authors declare that the research was conducted in the absence of any commercial or financial relationships that could be construed as a potential conflict of interest.

Copyright (c) 2019 Pontonio, Dingeo, Gobbetti and Rizzello. This is an open-access article distributed under the terms of the Creative Commons Attribution License (CC BY). The use, distribution or reproduction in other forums is permitted, provided the original author(s) and the copyright owner(s) are credited and that the original publication in this journal is cited, in accordance with accepted academic practice. No use, distribution or reproduction is permitted which does not comply with these terms. 